\title{
Total column water vapour measurements from GOME-2 MetOp-A and MetOp-B
}

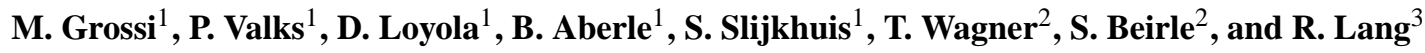 \\ ${ }^{1}$ Institut für Methodik der Fernerkundung (IMF), Deutsches Zentrum für Luft- und Raumfahrt (DLR), \\ Oberpfaffenhofen, Germany \\ ${ }^{2}$ MPI Chemistry, Hahn-Meitner-Weg 1, 55128 Mainz, Germany \\ ${ }^{3}$ EUMETSAT, Allee 1, 64295 Darmstadt, Germany \\ Correspondence to: M. Grossi (margherita.grossi@dlr.de)
}

Received: 18 December 2013 - Published in Atmos. Meas. Tech. Discuss.: 28 March 2014

Revised: 15 January 2015 - Accepted: 2 February 2015 - Published: 5 March 2015

\begin{abstract}
Knowledge of the total column water vapour (TCWV) global distribution is fundamental for climate analysis and weather monitoring. In this work, we present the retrieval algorithm used to derive the operational TCWV from the GOME-2 sensors aboard EUMETSAT's MetOp$\mathrm{A}$ and MetOp-B satellites and perform an extensive intercomparison in order to evaluate their consistency and temporal stability. For the analysis, the GOME-2 data sets are generated by DLR in the framework of the EUMETSAT O3MSAF project using the GOME Data Processor (GDP) version 4.7. The retrieval algorithm is based on a classical Differential Optical Absorption Spectroscopy (DOAS) method and combines a $\mathrm{H}_{2} \mathrm{O}$ and $\mathrm{O}_{2}$ retrieval for the computation of the trace gas vertical column density. We introduce a further enhancement in the quality of the $\mathrm{H}_{2} \mathrm{O}$ total column by optimizing the cloud screening and developing an empirical correction in order to eliminate the instrument scan angle dependencies. The overall consistency between measurements from the newer GOME-2 instrument on board of the MetOp-B platform and the GOME-2/MetOp-A data is evaluated in the overlap period (December 2012-June 2014). Furthermore, we compare GOME-2 results with independent TCWV data from the ECMWF ERA-Interim reanalysis, with SSMIS satellite measurements during the full period January 2007-June 2014 and against the combined SSM/I + MERIS satellite data set developed in the framework of the ESA DUE GlobVapour project (January 2007-December 2008). Global mean biases as small as $\pm 0.035 \mathrm{~g} \mathrm{~cm}^{-2}$ are found between GOME-2A and all other data sets. The combined SSM/I-MERIS sample and the ECMWF ERA-Interim
\end{abstract}

data set are typically drier than the GOME-2 retrievals, while on average GOME-2 data overestimate the SSMIS measurements by only $0.006 \mathrm{~g} \mathrm{~cm}^{-2}$. However, the size of these biases is seasonally dependent. Monthly average differences can be as large as $0.1 \mathrm{~g} \mathrm{~cm}^{-2}$, based on the analysis against SSMIS measurements, which include only data over ocean. The seasonal behaviour is not as evident when comparing GOME-2 TCWV to the ECMWF ERA-Interim and the SSM/I+MERIS data sets, since the different biases over land and ocean surfaces partly compensate each other. Studying two exemplary months, we estimate regional differences and identify a very good agreement between GOME-2 total columns and all three data sets, especially for land areas, although some discrepancies (bias larger than $\pm 0.5 \mathrm{~g} \mathrm{~cm}^{-2}$ ) over ocean and over land areas with high humidity or a relatively large surface albedo are observed.

\section{Introduction}

Water vapour is a key component of the Earth's atmosphere and has a strong impact on the Earth's radiative balance (Trenberth et al., 2007). It is the most potent natural greenhouse gas, owing to the presence of the hydroxyl bond which strongly absorbs in the infrared region of the light spectrum (Learner et al., 2000). As climate warms, the water vapour content in the atmosphere, which is described by the Clausius-Clapeyron equation, is expected to rise much faster than the total precipitation amount, which is governed by the surface heat budget through evaporation (Trenberth and 
Stepaniak, 2003). This means that there is a "positive water vapour feedback" which is expected to further amplify the original climate warming. On the other hand, the net effect of clouds on the climate is to cool down the Earth surface, at least under the current global distribution of clouds. Still unclear is the net cooling or warming effect of clouds in a changing atmosphere. In order to study this complex interaction and evaluate climate models, observations of the effective distribution of total column water vapour (TCWV) on a global scale are fundamental.

The water vapour distribution plays a major role for both meteorological phenomena and climate via its influence on the formation of clouds and precipitation, the growth of aerosols, and the reactive chemistry related to ozone and the hydroxyl radical. Hence, advancing our understanding of the variability and changes in water vapour is vital, especially considering that, in contrast to most other greenhouse gases, the $\mathrm{H}_{2} \mathrm{O}$ distribution is highly variable.

Despite the important role of water vapour, for a long time very little effort was spent on the validation and harmonization of experimental water vapour data sets. Only in 1993 was water vapour included in the list of greenhouse gases by the World Meteorological Organization (WMO) and difficulties in observing the water vapour in the troposphere have long hampered observations and modelling studies. In the 1990s, accurate measurement techniques began to be developed and, today, a large variety of in situ and remote sensing techniques for the measurement of integrated water vapour can be operated from different platforms. Nonetheless, significant limitations still remain in the coverage and reliability of humidity data sets.

Traditional humidity profiling with a ground-based radiosonde can provide water vapour profiles with good resolution under all weather conditions, but they are usually available only twice a day, at sparse locations over the globe (mostly industrialized areas and land surfaces), and they often contain systematic biases (Wang et al., 2002) and spurious changes (Gaffen et al., 1991). Sources of possible random errors and bias include sampling problems, bias due to the non-linear relationship among moisture variables (i.e. relative humidity, vapour pressure and temperature) and daytime versus nighttime soundings. Since 1994, when the global positioning system (GPS) became fully operational, considerable efforts have been made to develop and improve methods of deriving atmospheric water vapour using groundbased GPS measurements (e.g. Bevis et al., 1992, 1994; Rocken et al., 1993, 1997, 2000) at very high temporal resolution (about $30 \mathrm{~min}$ ).

Complementary to ground-based measurements, which provide accurate information on the $\mathrm{H}_{2} \mathrm{O}$ concentration, satellite observations offer the unique opportunity to study the spatial and temporal variability of water vapour on a global scale. They also allow us to assess the distribution of the column-integrated (the so-called total column) water vapour in remote places with none or only few in situ mea- surements, but they are typically limited in their vertical and temporal resolution. Most commonly used for the retrieval of water vapour from space are microwave sensors, e.g. the Special Sensor Microwave Imager (SSM/I), which are able to provide measurements at high spatial (horizontal) resolution (Bauer and Schluessel, 1993), but are usually constrained over ice-free ocean areas. Data from these instruments are operationally assimilated into numerical weather prediction reanalysis models like the ERA-Interim from the European Centre for Medium Range Forecasts (ECMWF, Dee et al., 2011a, b) and, until the beginning of this century, represented the only consistent long-timescale data set for water vapour. Sensors operating in the near infrared, like the Medium Range Resolution Imager Spectrometer (MERIS) on ENVISAT ( $\mathrm{Li}$ et al., 2006), can also derive water vapour over land, but cannot retrieve this product in cloudy conditions. Moreover, the very low albedo of the ocean surface in the near infrared limits retrieval in these areas. However, measurements are possible in sun-glint or above-cloud conditions over ocean, since these two conditions increase the surface albedo. Long-term water vapour observations in infrared bands are available from instruments such as Television Infrared Observation Satellite Program (TIROS) Operational Vertical Sounder (TOVS), Advanced TIROS Operational Vertical Sounder (ATOVS) and Atmospheric Infrared Sounder (AIRS) (e.g. Chaboureau et al., 1998; Li et al., 2000; Susskind et al., 2003). Temperature and moisture profiles with a vertical resolution of about $2-5 \mathrm{~km}$ can also be obtained from the Interferometric Monitor for Greenhouse gases (IMG, e.g. Ogawa et al., 1994), the Tropospheric Emission Spectrometer (TES, e.g. Shephard et al., 2008; Worden et al., 2012) and the Infrared Atmospheric Sounding Interferometer (IASI, e.g. Clerbaux et al., 2009; Hilton et al., 2012). Satellite infrared observations can distinguish different tropospheric layers, but have the disadvantage of being less sensitive to the surface emission from the lowest layers, where most of the atmospheric water vapour is present. This type of observation also requires model input for the retrieval. A recently developed method for the retrieval of water vapour distribution is the utilization of data from the GPS satellites (see, e.g. Dai et al., 2002). Despite the relatively small spatial coverage, GPS measurements from space and the ground are valuable because their information complements that provided by satellite radiance measurements.

Sensors covering the ultraviolet, visible and near infrared range (UVN) with a relative high spectral resolution, e.g. the Global Ozone Monitoring Experiment (GOME) on European Remote Sensing (ERS) satellite ERS-2 (Burrows et al., 1999), can accurately map the column densities of the atmospheric $\mathrm{H}_{2} \mathrm{O}$ over all surfaces. The analysis is performed in the visible spectral range, where the radiation comes mainly from surface reflection, or, above dark surfaces, from tropospheric Rayleigh scattering. These measurements are thus very sensitive to the $\mathrm{H}_{2} \mathrm{O}$ layers close to the surface, but, similar to MERIS, the retrievals are typically hampered by 
clouds. GOME data have been used, among others, for the study of long-term variations in tropospheric water vapour trends (Mieruch et al., 2008; Wagner et al., 2006) and to monitor and investigate inter annual climate variability phenomena observed on Earth, such as El Niño/La Niña (Wagner et al., 2005; Loyola et al., 2006). A second generation of this kind of instrument is represented by the Scanning Imaging Absorption Spectrometer for Atmospheric Chartography (SCIAMACHY, Bovensmann et al., 1999), on the ENVISAT platform. Current operational UVN sensors are the Global Ozone Monitoring Experiment-2 (GOME-2) instruments, the subject of the current study, on board the MetOpA and MetOp-B satellites (hereafter GOME-2A and GOME2B sensors). The GOME-2 spectrometers lay the foundation for a consistent data record of $\mathrm{H}_{2} \mathrm{O}$ GOME-type observations, which already spans more than 18 years and will be further extended by GOME-2/MetOp-C, a third satellite which is planned to be launched in 2018.

TCWV from measurements of the GOME-2 instruments aboard EUMETSAT's MetOp-A and MetOp-B satellites has already proved to be a valuable input quantity for climate models (Noël et al., 2008; Slijkhuis et al., 2009; Kalakoski et al., 2011; Mieruch et al., 2010), and could be useful for assimilation into numerical weather prediction models, e. g. for following dynamical structures in water vapour when a high absolute accuracy is not required. In contrast to other satellite data sets, the GOME- 2 product has the advantage that it covers the entire Earth, including both ocean and continents, leading to a more consistent picture of the global distribution of the atmospheric humidity. Long-term satellite data sets are essential for atmospheric monitoring and the impact of human intervention in a changing environment has brought about increasing concern for detecting trends in water vapour.

In this paper, we present the $\mathrm{H}_{2} \mathrm{O}$ retrieval algorithm used for the operational EUMETSAT's Satellite Application Facility on Ozone and Atmospheric Chemistry Monitoring (O3M-SAF) water vapour products from the GOME-2 sensors and we compare it with independent satellite instruments and model data. On the basis of this comparison, we are able to estimate the accuracy of the retrieval algorithm and we can make an assessment of the quality and consistency of GOME-2 TCWV product.

The validation of the GOME-2 TCWV produced with an earlier version of the retrieval algorithm was already presented in Kalakoski et al. (2011). From the comparison with radiosondes, a mean positive bias of $0.11 \mathrm{~g} \mathrm{~cm}^{-2}$ was found, while from the comparison with SSM/I products typical biases of about $0.2 \mathrm{~g} \mathrm{~cm}^{-2}$ were retrieved for monthly global averages. More recently, the ESA DUE GlobVapour project (Schröder et al., 2012a) has focused on the development of multi-annual global water vapour data sets and, among other deliverables, has provided a first version of a consistent TCWV data set from the GOME, SCIAMACHY and GOME-2 sensors for the time period 1996-2008. In the framework of the GlobVapour project, extensive validation activities were carried out, pointing to large differences with positive and negative bias values on regional scales (Schröder et al., 2012c). The variability of the bias was found to be generally large (on the order of $0.2 \mathrm{~g} \mathrm{~cm}^{-2}$ ). It was observed that the GOME/SCIAMACHY/GOME-2 product tends to be drier than the compared ground-based and satellite data (including Global Upper-Air Network (GUAN) stations, three Atmospheric Radiation Measurement (ARM) radiosonde sites and ATOVS data) with the exception of AIRS (Aqua) (mean bias $0.16 \mathrm{~g} \mathrm{~cm}^{-2}$ ). Larger differences on a regional basis were observed in the comparison with SSM/I+MERIS with negative bias $\left(-0.1 \mathrm{~g} \mathrm{~cm}^{-2}\right)$ over ocean and smaller positive bias in land regions $\left(0.03 \mathrm{~g} \mathrm{~cm}^{-2}\right)$. Also in this case, a previous version of the GOME-2 TCWV algorithm was used.

A detailed description of the global validation of the newest operational GOME-2 TCWV product, using radiosonde data from the Integrated Radiosonde Archive (IGRA) and GPS data from the COSMIC/SuomiNet network, can be found in Kalakoski et al. (2014). The comparison was performed for the period December 2012-July 2013, using the latest operational water vapour product. A good agreement of both GOME-2A and GOME-2B with groundbased data sets is observed. GOME-2 data show small negative (dry) median difference against radiosonde (GOME2A: $-2.7 \%$; GOME-2B: $-0.3 \%$ ) and positive (wet) median difference against GPS observations (GOME-2A: $4.9 \%$; GOME-2B: $3.2 \%$ ). For TCWV below $1 \mathrm{~g} \mathrm{~cm}^{-2}$, large wet biases are observed, especially against GPS observations. Conversely, at values above $5 \mathrm{~g} \mathrm{~cm}^{-2}$, GOME-2 generally underestimates both ground-based observations. In Antón et al. (2014), the authors validate the GOME-2 data set against six reference atmospheric sounding data sets obtained from the GCOS Reference Upper-Air Network (GRUAN). They found a reasonably good correlation between GOME-2 and sounding TCWV data (determination coefficient $\left(R^{2}\right)$ of 0.89 ). A remarkable improvement of the correlation was found by selecting cloud-free cases $\left(R^{2}=0.95\right)$. Also in this study, the satellite-sounding differences showed a strong negative dependence on the magnitude of the reference TCWV values.

The remainder of this paper is organized as follows. After a short description of the GOME-2 instruments in the following, Sect. 3 gives a detailed overview of the $\mathrm{H}_{2} \mathrm{O}$ retrieval algorithm and introduces the TCWV data used for the comparison with model data and independent satellite measurements. In Sect. 4, the GOME-2 water vapour columns from MetOp$\mathrm{A}$ and MetOp-B are compared during their overlapping time frame January 2013 through June 2014. A quantitative analysis of the distribution of daily and monthly mean biases is performed. The results of the comparisons with ECMWF ERA-Interim data and satellite measurements from SSMIS, SSM/I and MERIS for the full period January 2007-June 
Table 1. Summary of the GOME-type instrument characteristics, illustrating the main improvement of GOME-2 compared to its predecessor GOME/ERS-2. (*) GOME-2A tandem operation since 15 July 2013. (**) GOME global coverage lost in June 2003.

\begin{tabular}{l|c|c|c|c}
\hline $\begin{array}{l}\text { Sensor } \\
\text { satellite }\end{array}$ & $\begin{array}{c}\text { GOME } \\
\text { ERS-2 }\end{array}$ & $\begin{array}{c}\text { SCIAMACHY } \\
\text { ENVISAT }\end{array}$ & $\begin{array}{c}\text { GOME-2 } \\
\text { MetOp-A }\end{array}$ & $\begin{array}{c}\text { GOME-2 } \\
\text { MetOp-B }\end{array}$ \\
\hline Data period & $06 / 1995-$ present & $08 / 2002-04 / 2012$ & $01 / 2007-$ present & $12 / 2012-$ present \\
Spectral coverage & $240-790 \mathrm{~nm}$ & $240-2380 \mathrm{~nm}$ & $240-790 \mathrm{~nm}$ & $240-790 \mathrm{~nm}^{2}$ \\
Ground pixel size & $320 \times 40 \mathrm{~km}^{2}$ & $60 \times 30 \mathrm{~km}^{2}$ & $80 \times 40 \mathrm{~km}^{2}-40 \times 40 \mathrm{~km}^{2}\left(^{*}\right)$ & $80 \times 40 \mathrm{~km}^{2}$ \\
Swath width & $960 \mathrm{~km}$ & $960 \mathrm{~km}$ & $1920 \mathrm{~km}-960 \mathrm{~km}\left(^{*}\right)$ & $1920 \mathrm{~km}$ \\
Equator crossing time & $10: 30$ a.m. LT & $10: 00$ a.m. LT & $09: 30$ a.m. LT & $09: 30$ a.m. LT \\
Global coverage & 3 days(**) & 6 days & 1.5 days & 1.5 days \\
\hline
\end{tabular}

2014 are illustrated in Sect. 5. Finally, conclusions are drawn in Sect. 6.

\section{GOME-2 instruments}

The GOME-2 sensor (Callies et al., 2000) is the follow up of the Global Monitoring Experiment (GOME), launched in 1995 on ERS-2 (Burrows at al., 1999), and the SCIAMACHY sensor, launched in 2002 on ENVISAT (Bovensmann et al., 1999). GOME-2 is a nadir viewing scanning spectrometer which covers the same spectral range as GOME, i.e. from 240 to $790 \mathrm{~nm}$, with a spectral resolution of about $0.54 \mathrm{~nm}$ in the visible spectral region. Additionally, two polarization components are measured with polarization measurement devices (PMDs) using 30 broadband channels covering the full spectral range at higher spatial resolution. The German Aerospace Centre (DLR) plays a major role in the design, implementation and operation of the GOME-2 ground segment for trace gas products, including TCWV, as well as cloud properties in the framework of the EUMETSAT O3M-SAF project.

We can identify important differences between the GOME instrument on the ERS-2 satellite and the GOME-2 sensors (Munro et al., 2006). First, the spatial resolution of the GOME data is $320 \times 40 \mathrm{~km}^{2}$, whereas the GOME-2 instruments have a smaller nominal ground pixel size (typically $80 \times 40 \mathrm{~km}^{2}$ ). Because of the improved spatial resolution, GOME-2 data are less influenced by partly cloudy scenes and the instruments are also able to detect strong spatial gradients in the $\mathrm{H}_{2} \mathrm{O}$ distribution. Second, the default swath width of the GOME-2 scan is $1920 \mathrm{~km}$, while both GOME and SCIAMACHY have a scan width of $960 \mathrm{~km}$. Therefore, the GOME-2 instruments employ only about 1.5 day to reach global coverage at the equator, while GOME/ERS-2 requires about three days ${ }^{1}$. In Table 1, we summarize the characteristics of the different GOME-type sensors.

The first GOME-2 instrument was mounted on the MetOpA satellite (GOME-2A), which follows a sun-synchronous

\footnotetext{
${ }^{1}$ After the failure of the ERS-2 tape recorder in June 2003, GOME measurements have been limited to the northern hemisphere and the Antarctic.
}

orbit with a mean altitude of $817 \mathrm{~km}$. The overpass local time at the equator is 09:30 Local Time (LT) with a repeat cycle of 29 days. MetOp-A was launched on 19 October 2006 and GOME-2 TCWV products are available from January 2007 onwards. A second GOME-2 type sensor on board of the MetOp-B satellite (GOME-2B) was launched on the 17 September 2012 and has been fully operational since December 2012. GOME-2 tandem operations started on 15 July 2013. In the tandem mode, GOME-2A operates on a reduced swath width of $960 \mathrm{~km}$, thereby increasing its spatial resolution ( 40 by $40 \mathrm{~km}$ ), while GOME-2B continues to operate on a nominal wide swath of $1920 \mathrm{~km}$. This configuration allows the use of the higher spatial resolution data to further study the consistency of the two products in the overlap regions of the GOME-2A and GOME-2B orbits.

The third and final satellite of the EUMETSAT Polar System series, GOME-2/MetOp-C, is planned to be launched in 2018, guaranteeing the continuous delivery of high-quality $\mathrm{H}_{2} \mathrm{O}$ data until 2023.

\section{GDP $4.7 \mathrm{H}_{2} \mathrm{O}$ column algorithm}

In the framework of the EUMETSAT O3M-SAF project, the algorithm used to generate the operational water vapour product is the level-1-to-2 GOME Data Processor (GDP) version 4.7, integrated into the Universal Processor for Atmospheric Spectrometers (UPAS, version 1.3.9) processing system at DLR and developed at the Max Planck Institute for Chemistry (MPI-C, Mainz).

Various retrieval methods of the TCWV from space-born spectrometers operating in the visible region have been developed (AMC-DOAS: Noël et al., 1999, Lichtenberg et al., 2010; ERA: Casadio et al., 2000; OCM: Maurellis et al., 2000; IGAM: Lang et al., 2003, 2007; Classical DOAS: Wagner et al., 2003). In contrast to most other methods, the GDP 4.7 algorithm for the retrieval of water vapour is directly based on a classical Differential Optical Absorption Spectroscopy (DOAS, Platt, 1994), performed in the wavelength interval $614-683 \mathrm{~nm}$, and does not include explicit numerical modelling of the atmospheric radiative transfer. One specific advantage of the DOAS method is that it is only sensitive to 
differential absorptions, which makes the retrievals less sensitive to instrument changes or instrument degradation.

The algorithm consists of three basic steps (described in detail by Wagner et al., 2003, 2006): (1) DOAS fitting, (2) non-linearity absorption correction and (3) vertical column density (VCD) calculation.

In the first step, the spectral DOAS fitting is carried out, taking into account absorption by $\mathrm{O}_{2}$ and $\mathrm{O}_{4}$, in addition to that of water vapour. A single $\mathrm{H}_{2} \mathrm{O}$ cross section is used, based on line-by-line computations using HITRAN (Rothman et al., 2009) $\mathrm{H}_{2} \mathrm{O}$ line parameter for a fixed temperature and pressure of $290 \mathrm{~K}$ and $900 \mathrm{hPa}$, followed by a GOME2 slit function convolution. In Wagner et al. (2003), the authors investigated the temperature and pressure dependence of the $\mathrm{H}_{2} \mathrm{O}$ absorption structure by varying the temperature by $\pm 20 \mathrm{~K}$ and the pressure by $\pm 100 \mathrm{hPa}$. The analysis of the GOME-2 measurements using these different $\mathrm{H}_{2} \mathrm{O}$ spectra yielded $\mathrm{H}_{2} \mathrm{O}$ SCDs varying by only $\pm 3 \%$. To improve the broadband filtering, three types of vegetation spectra are included in the fit. They are included also over water, as marine chlorophyll-containing substances may show similar effects and can cause strong interference with atmospheric absorbers (Wagner et al., 2007). In addition, we use a synthetic ring spectrum calculated from the Sun's spectrum (Gomer et al., 1993; Wagner et al., 2009) to correct for the ring effect (filling-in of well-modulated solar and absorption features in the Earth shine spectra) and, finally, an inverse solar spectrum to compensate for possible offsets, e.g. caused by instrumental stray light.

Since the highly fine structured $\mathrm{H}_{2} \mathrm{O}$ (and $\mathrm{O}_{2}$ ) absorption bands cannot be spectroscopically resolved by the GOME2 instrument, the water vapour slant column density (SCD: the concentration integrated along the light path) is no more a linear function of the atmospheric $\mathrm{H}_{2} \mathrm{O}$ column density (Solomon et al., 1989; Wagner et al., 2000). In the second step of our retrieval, we therefore apply a correction for the absorption non-linearity effect. The correction factors are calculated from numerical simulations of this effect by mathematical convolution of the high resolved $\mathrm{H}_{2} \mathrm{O}$ spectrum with the instrument slit function (Van Roozendael et al., 1999; Wagner et al., 2003). This effect can become important especially in the tropics, for large $\mathrm{H}_{2} \mathrm{O}$ SCDs. For example, for an atmospheric $\mathrm{H}_{2} \mathrm{O}$ SCDs of $1.5 \times 10^{23} \mathrm{~mol} \mathrm{~cm}^{-2}$ $\left(\sim 4.5 \mathrm{~g} \mathrm{~cm}^{-2}\right)$, the underestimation is about $30 \%$.

In the last step, the corrected water vapour slant columns determined with the DOAS fitting are converted to geometryindependent vertical column densities (VCDs) through division by an appropriate air mass factor (AMF), which, in this case, is derived from the measured $\mathrm{O}_{2}$ absorption. We divide the $\mathrm{H}_{2} \mathrm{O}$ SCD by a "measured" AMF, which is defined as the ratio between the simultaneously retrieved $\mathrm{SCD}$ of $\mathrm{O}_{2}$ and the known VCD of $\mathrm{O}_{2}$ for a standard atmosphere. The de- sired TCWV is computed as follows:

$\Omega_{\mathrm{H}_{2} \mathrm{O}, 0}=\frac{\Omega_{\mathrm{H}_{2} \mathrm{O}, \theta}}{A_{\mathrm{O}_{2}}}=\frac{\Omega_{\mathrm{H}_{2} \mathrm{O}, \theta}}{\Omega_{\mathrm{O}_{2}, \theta} / \Omega_{\mathrm{O}_{2}, 0}}$,

where $\Omega_{x, 0}$ is the VCD, $\Omega_{x, \theta}$ is the SCD and $A_{x}$ is the AMF of the chemical species $x$. This simple approach has the advantage that it corrects in first order for the effect of varying albedo, aerosol load and cloud cover using the satellite observations themselves, without additional independent information which is usually also not available. However, the underlying assumption that the AMF of $\mathrm{O}_{2}$ is similar to the AMF for water vapour can produce systematic differences in the retrieval. Because the vertical profile of $\mathrm{H}_{2} \mathrm{O}$ is much more peaked in the troposphere with respect to that of $\mathrm{O}_{2}$ (the $\mathrm{H}_{2} \mathrm{O}$ scale height is only about $2 \mathrm{~km}$ compared to $8 \mathrm{~km}$ for $\mathrm{O}_{2}$ ), the measured AMF derived from the $\mathrm{O}_{2}$ absorption is in general larger than the AMF for water vapour. In the case of low lying clouds, for example, the dominant part of the $\mathrm{H}_{2} \mathrm{O}$ total column is located near the surface and therefore shielded, while most of the $\mathrm{O}_{2}$ contribution is still above the clouds.

The errors in the individual TCWV measurements due to the application of an $\mathrm{O}_{2} \mathrm{AMF}$ can be quite large. One possibility for reducing these errors would be to use the appropriate $\mathrm{H}_{2} \mathrm{O}$ AMFs derived from radiative transfer (RT) calculations instead. In the future, we plan to identify, and possibly correct, the influence of clouds and surface albedo on the TCWV using the LIDORT RT model (Spurr et al., 2008). However, such calculations are complicated because typically the atmospheric aerosol extinction profile is not known, and clouds strongly affect RT calculations. Because of these difficulties, we follow a different approach here: we introduce a correction factor look-up table in the AMF computation:

$\Omega_{\mathrm{H}_{2} \mathrm{O}, 0}=\frac{\Omega_{\mathrm{H}_{2} \mathrm{O}, \theta}}{A_{\mathrm{O}_{2}}} \times C_{\text {ratio }}=\frac{\Omega_{\mathrm{H}_{2} \mathrm{O}, \theta}}{\Omega_{\mathrm{O}_{2}, \theta} / \Omega_{\mathrm{O}_{2}, 0}} \times C_{\text {ratio }}$.

The factor $C_{\text {ratio }}$ depends on the solar zenith angle (SZA), on the line of sight angle (LOS) and relative azimuth (RAZ) of the satellite instrument and on the surface albedo (Alb). Moreover, the exact vertical profile of $\mathrm{H}_{2} \mathrm{O}$ in the troposphere and the cloud cover have a strong impact. The correction factors were derived from radiative transfer calculations using the Monte Carlo Atmospheric Radiative Transfer Inversion Model (McArtim, Deutschmann et al., 2011), taking into account an average $\mathrm{H}_{2} \mathrm{O}$ profile calculated from relative humidity profiles assuming an average lapse rate (Minschwaner and Dessler, 2004; Wagner et al., 2006) and an $\mathrm{O}_{2}$ profile from the US standard atmosphere. The relative sensitivity of the measured $\mathrm{O}_{2}$ absorption compared to $\mathrm{H}_{2} \mathrm{O}$ absorption also varies significantly depending on surface albedo values. In the radiative transfer model (RTM), the correction factor was computed assuming a fixed surface albedo of $2 \%$ and cloudfree conditions. Similar results are obtained assuming 3\% 
surface albedo over ocean and 5\% cloud fraction (Wagner et al., 2011). The albedo database derived from GOME observations (Koelemeijer et al., 2003) at high latitude $\left(>50^{\circ}\right)$ and from SCIAMACHY observations (Grzegorski, 2009) at mid and low latitudes $\left(>40^{\circ}\right)$ was used in order to derive the dependency of the computed AMFs to the actual surface albedo. It should be mentioned that the global surface albedo map described above is the only external information needed in the retrieval algorithm (in addition to the average $\mathrm{H}_{2} \mathrm{O}$ and $\mathrm{O}_{2}$ profiles). Since it does not rely on other external input data, the GOME-2 TCWV product is especially valuable for long-term series and climatological studies.

\subsection{Error budget and cloud masking}

The error budget in the $\mathrm{H}_{2} \mathrm{O}$ product can be separated into two parts: errors affecting the retrieval of the slant columns (DOAS-related errors), and errors affecting the conversion of the SCD into VCD (AMF-related errors). However, these latter errors are difficult to quantify, because the water vapour AMF is not based on explicit RT calculations, and there may be compensating effects. For example, in the case of snow surfaces, the high surface reflectivity would lead to a relatively high sensitivity for $\mathrm{H}_{2} \mathrm{O}$ in the lower troposphere, and hence a lower AMF-ratio of $\mathrm{O}_{2}$ to $\mathrm{H}_{2} \mathrm{O}$, but above cold surfaces the tropospheric $\mathrm{H}_{2} \mathrm{O}$ column is reduced, causing the opposite effect. The following potential error sources are taken into account: relative fit error of $\mathrm{H}_{2} \mathrm{O}$ and $\mathrm{O}_{2}$, uncertainties in the spectroscopic data (about $10 \%$ ) and especially uncertainties due to clouds. The total, relative error can be derived by the following formula (Wagner et al., 2011):

$\Delta_{\text {total }}=\sqrt{\Delta_{\mathrm{H}_{2} \mathrm{O}}^{2}+\Delta_{\mathrm{O}_{2}}^{2}+(0.1)^{2}+\Delta_{\mathrm{RTM}}^{2}}$.

The source of error due to clouds $\left(\Delta_{\mathrm{RTM}}^{2}\right)$ increases with decreasing $\mathrm{O}_{2} \mathrm{SCD}$, indicating strong cloud shielding. Therefore, on the GOME- $2 \mathrm{H}_{2} \mathrm{O}$ product, cloudy conditions are flagged.

In our latest version of the retrieval algorithm (GDP 4.7), two cloud indicators are used to identify and flag cloudy pixels. This is necessary to remove potential systematic cloud effects due to the different altitude profiles of $\mathrm{H}_{2} \mathrm{O}$ and $\mathrm{O}_{2}$ which might still appear in the water vapour product. The first cloud flag is set if the product of cloud fraction and cloud-top albedo exceeds 0.6 (anomalously high cloud-top reflection). In this case, the $\mathrm{H}_{2} \mathrm{O}$ total column is also set to "invalid" as the pixel might be considered fully clouded. The GOME-2 cloud fraction is determined with the OCRA algorithm using broadband radiance measurements in the UV/VIS range, while cloud-top height and cloud-top albedo are retrieved with the ROCINN algorithm using the spectral information in the Oxygen-A band in and around 760 $\mathrm{nm}$ (Loyola et al., 2007 and 2010). The GOME-2 detector sequential read-out may induce spatial aliasing effects for highly inhomogeneous scenes in the case that the retrievals use measurements far away from the $\mathrm{O}_{2}$ band. The PMD measurements are aligned to the $\mathrm{O}_{2}$ A-band measurements (end of channel 4) to avoid spatial aliasing effects between the OCRA/ROCINN derived cloud properties. Possible spatial aliasing effects between the cloud properties and the water vapour measurements (beginning of channel 4) are minimized by using a conservative cloud screening scheme.

The second $\mathrm{H}_{2} \mathrm{O}$ cloud flag is set if the retrieved $\mathrm{O}_{2}$ slant column is below $80 \%$ of the maximum $\mathrm{O}_{2} \mathrm{SCD}$ for the respective solar zenith angle (roughly when about $20 \%$ from the column to ground is missing). Especially for low and medium high clouds, the relative fraction of the VCD from the ground which is shielded by clouds for $\mathrm{O}_{2}$ and $\mathrm{H}_{2} \mathrm{O}$ can be quite different. Therefore, we require that the main part of the $\mathrm{O}_{2}$ column is present. The maximum values of the $\mathrm{O}_{2}$ SCD have been derived from measured optical depth of the $\mathrm{O}_{2}$ absorption along GOME satellite orbits as a function of the solar zenith angles and implemented in a look-up table in the retrieval code. We also consider the line of sight dependence of the $\mathrm{O}_{2}$ threshold for mainly cloud-free observations by multiplication for an additional function (Wagner et al., 2011). The choice of having a threshold of $80 \%$ of the maximum values represents a good compromise with respect to the number of measurements still available after selection and the correction of the strongest cloud effects on the TCWV product. This second cloud flag also rejects observations with high surface elevation, e.g. the Himalayas or the Andes.

\subsection{Scan angle dependency correction}

As already mentioned, the GOME-2 observations have a much wider swath compared to GOME and SCIAMACHY (see Table 1). While this broader swath results in a largely improved coverage, some modifications to the $\mathrm{H}_{2} \mathrm{O}$ retrieval become necessary. In particular, we observe that the GOME2 total column water vapour presents a significant Scan Angle Dependency (SAD), which strongly affects the quality of the product. This scan angle dependency is very similar for MetOp-A and MetOp-B, while a SAD is also observed in other trace gas retrievals from GOME-2, such as $\mathrm{O}_{3}$ and $\mathrm{NO}_{2}$ columns.

There is a bias up to $1 \mathrm{~g} \mathrm{~cm}^{-2}$ between the $\mathrm{H}_{2} \mathrm{O}$ total columns for the west and east part of the swath and the central ground pixels. This effect is particularly strong over ocean areas, while the land surface is less affected. There are two major contributing factors. First, the accuracy of the retrieved TCWV is reduced because of sun-glint over ocean regions which may strongly enhance the back-scattered radiation, especially at low wind speed (highly specular reflection). In this case, the observations are contaminated by the bright pattern of the specular reflection of the Sun by the wavy sea surface. The GOME-2 algorithm can distinguish sun-glint areas by analysing the broadband polarization measurements (Loyola et al., 2011), but the pixels we select 

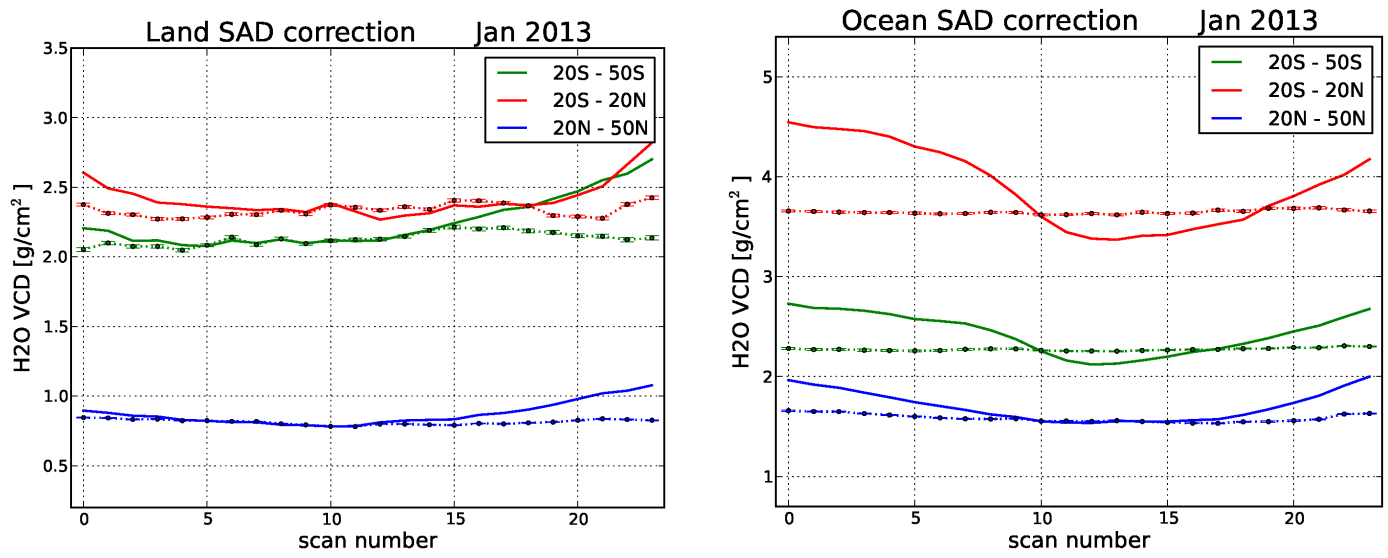

Figure 1. GOME-2A total column water vapour as a function of the number of the pixel index within the scan $(0=$ east, $24=$ west $)$ averaged in different latitude bands $\left(20-50^{\circ} \mathrm{S}, 20^{\circ} \mathrm{S}-20^{\circ} \mathrm{N}, 20^{\circ}-50^{\circ} \mathrm{N}\right)$ before (solid line) and after (dashed line with points) the SAD correction for January 2013. We show separately the empirical correction applied over land measurements (left panel) and over ocean measurements (right panel). The error bars represent the spread of the water vapour data points. The statistical bias as a function of the scan angle is well determined due to the large number of measurements.

with this method (typically less than $4 \%$ of the total) represent only few measurements in extreme sun-glint geometry. Therefore, we still require a correction for the small signal of water-leaving radiances in directions away from the glitter. Second, the accuracy of the surface albedo data available for the oceans is limited, and therefore a constant albedo (0.03) is used in the AMF calculation for the sea surface (Grzegorski et al., 2004).

An accurate analysis of the GOME- $2 \mathrm{H}_{2} \mathrm{O}$ total columns retrieved with a previous version of the GDP algorithm (GDP 4.6) revealed a systematic SAD already in the $\mathrm{H}_{2} \mathrm{O} S C D$, especially for cloud-free pixels. This suggested a correlation between a simplified Lambertian assumption used to describe the Earth reflectivity and the SAD. From radiative transfer calculations using bidirectional reflectance distribution function (BRDF) kernels based on a Cox-Munk distribution (Cox and Munk, 1954), we found that using a simple Lambertian approach and ignoring the BRDF, we underestimate the AMF over ocean in the east regions of the scan (and overestimate it in the west regions) up to $30 \%$ (Valks et al., 2012). Some residual line of sight dependence is likely due to the Rayleigh single scattering contribution, since the instrument is polarization sensitive. Moreover, in order to compute the $\mathrm{H}_{2} \mathrm{O}$ total column, we use the simultaneously observed $\mathrm{O}_{2}$ slant column density. A correction factor accounts for the different altitude profile of $\mathrm{H}_{2} \mathrm{O}$ and $\mathrm{O}_{2}$ (the factor $C_{\text {ratio }}$ mentioned in Sect. 3). Since the look-up tables containing the correction factors are computed for average conditions of cloud cover, albedo, and a single $\mathrm{H}_{2} \mathrm{O}$ profile, some residual $\mathrm{SAD}$ might remain, especially in more extreme atmospheric scenarios.

In GDP 4.7, we introduce an empirical statistical correction for the scan angle dependency, based on the full six-year time series of GOME-2/MetOp-A measurements (2007-
2012). Multi-annual monthly mean $\mathrm{H}_{2} \mathrm{O}$ total columns are created and employed to select the latitudinal binned regions which contain a sufficiently large number of measurements. We require that, for a latitude band $\left(1^{\circ}\right)$, the ratio between the number of water vapour measurements with a given pixel number and with pixel number used for the normalization does not vary by more than $20 \%$. In this way, we avoid the correction being affected by natural variability in the $\mathrm{H}_{2} \mathrm{O}$ total columns. We use scan angle read-outs toward the nadir scan angle (scan pixel numbers 9-10-11) as reference values to normalize the $\mathrm{H}_{2} \mathrm{O}$ total column for every forward angle position and derive a self-consistent correction. This is done because scan angle measurements close to the nadir direction show the best agreement in comparisons with ground-based and satellite observations. Finally, a polynomial is fitted to the normalized measurements in order to remove outliers and obtain a smooth correction function. With our procedure, residuals are on the order of a few percent. Outside the valid latitudinal range, an interpolation between the last valid value and 1 (i.e. no correction) for $\pm 90^{\circ}$ latitude is performed. A similar algorithm was originally developed for correcting the scan-angle dependency of GOME-2 total ozone product (Loyola et al., 2011).

Two different corrections are implemented over land and over sea, to take into account the diverse reflectivity properties of the surface. We found that the biases between east and west pixels are related to the viewing geometry. The correction values depend on the surface type (land or ocean), the scattering angle (pixel scan number) and the latitude, and vary from month to month. In the left panel of Fig. 1, we depict the SAD correction for land, while in the right panel the correction applied over ocean regions is shown. In both figures we can distinguish the TCWV before (solid line) and after (dashed line) the empirical correction for the 
scan angle dependency. The lines refer to latitudinal averaged quantities in the northern, tropical and southern hemisphere regions for January 2013. While in austral summer (December-February) the correction is larger in the $20^{\circ}-50^{\circ}$ south regions, in the northern hemisphere summer months (June-August), it is larger for the $20^{\circ}-50^{\circ}$ north region. The error bars in Fig. 1 represent the spread of the water vapour data points (defined as $\mathrm{SE}=S / \sqrt{N}$, where $S$ is the standard deviation of the sample mean and $N$ the number of measurements). Because of the large natural variability in the spatial distribution of the water vapour data, the standard deviation is quite large. Nevertheless, the statistical bias as a function of the scan angle is well determined due to the large number of measurements.

Figure 2 shows the global distribution of the $\mathrm{H}_{2} \mathrm{O}$ total columns derived from GOME-2B measurements for the 7 January 2013 (before the tandem operation mode) with (right panel) and without (left panel) SAD correction, for cloudscreened measurements only. The empirical SAD correction based on 6 full years of GOME-2A data is also consistently applied to the GOME-2B product (the scan angle dependency of the TCWV product is similar for both GOME-2 sensors). The white regions in the map show the areas where the product of cloud fraction and cloud-top albedo exceeds 0.6 , while the $\mathrm{O}_{2}$ cloud screening rejects mostly GOME2 measurements over the west part of scan, since these are measurements with small AMF and low GOME-2 sensitivity for $\mathrm{H}_{2} \mathrm{O}$. The net effect of the empirical correction is a reduced bias in the total column water vapour distribution between the east and west part of the GOME-2 orbit. Differences between TCWV product derived with and without SAD correction for the 7 January 2013 are shown in Fig. 3. The bias is especially high in the equatorial region, where the $\mathrm{H}_{2} \mathrm{O}$ total column presents lower values in the east part of the scan when applying the SAD correction (e.g. over the Indian Ocean, east of Madagascar) and smaller and positive values in the west part of the scan (see the orange-red regions over South America, and the Pacific and Indian Oceans). In all subsequent analyses, the GOME- 2 data are generated with the new version of the retrieval algorithm including the SAD correction, unless otherwise stated.

GOME-2 Level 2 TCWV and cloud products generated using the GDP 4.7 algorithm are available from the DLR ftp server in HDF5 format. Information about the operational water vapour product can be found at http://atmos.caf.dlr.de/ gome2. Documents, reports, quick-look maps and links to related information are also available on this website.

\section{GOME-2A vs. GOME-2B}

We compare the GOME-2/MetOp- $\mathrm{B}_{2} \mathrm{O}$ total columns with those from its predecessors GOME-2/MetOp-A, based on more than one and a half years of overlap between the two satellites, from December 2012 to June 2014. We perform the inter-comparison between GOME-2A and GOME-2B data taking into account either (mostly) cloud-free or all available measurements for one particular day and monthly means. For the monthly comparison, we first analyse the spatial distribution of the bias from gridded monthly mean GOME-2A and GOME-2B water vapour columns. Then, in order to make the data selection in the two instruments as similar as possible, a comparison using only co-located measurements is performed. A quantitative analysis of the bias between GOME$2 \mathrm{~A}$ and GOME-2B as a function of the latitude concludes this section.

\subsection{Daily GOME-2 comparison}

In the top panels of Fig. 4, we show a map of the $\mathrm{H}_{2} \mathrm{O}$ total columns for the 7 January 2013 from GOME-2A (left panel) and GOME-2B (right panel) measurements to provide a first illustration of the geophysical consistency of the TCWV products from the different instruments. In both cases, we applied a SAD correction over ocean and land areas. Overall, we observe a very good agreement between the two data sets and the same spatial patterns in the humidity distribution, with high values in the tropics and low humidity at higher latitudes. Since the GOME-2 products are only derived from daylight observations, a large area around the Arctic is blanked out in the northern hemispheric winter. Here, we do not apply any cloud mask to the data to show the daily coverage of the two GOME-2 instruments.

In the bottom panels of Fig. 4, we investigate the differences between GOME-2A and GOME-2B TCWV for the 7 January 2013, when the SAD correction is applied to the two data sets (right panel), and without SAD correction (left panel). The inter-comparison has been performed using cloud-free and co-located pixels. Co-location areas are determined applying the following criteria: $55 \mathrm{~km}$ for the maximum distance between two measurements in the chosen day. In the tropics, the number of measurements is drastically reduced mainly because we have the smallest overlap between the GOME-2A and GOME-2B orbits, but also because of the larger chance of clouds. On average, the TCWV for GOME$2 \mathrm{~B}$ is slightly higher than for the GOME-2A product, independent of the presence of a SAD correction in the two data sets (i.e. if we use GDP 4.6 or GDP 4.7 retrieval), with mean bias values of $-0.05 \mathrm{~g} \mathrm{~cm}^{-2}$ and a standard deviation of about $0.5 \mathrm{~g} \mathrm{~cm}^{-2}$.

The GOME-2A and GOME-2B co-planar orbits are $174^{\circ}$ out of phase. This results in a temporal separation of the measurements at co-locations of approximately $48 \mathrm{~min}$, and leads to differences in the TCWV because of tropospheric dynamics. The overall mean bias does not change significantly using the GOME-2 data with and without the SAD correction. However, because of the additional scan-angle bias, at single locations the difference between GOME-2A and GOME-2B TCWV is larger without SAD correction, as we can see by comparing the left and right plots of Fig. 4. This is due to the 

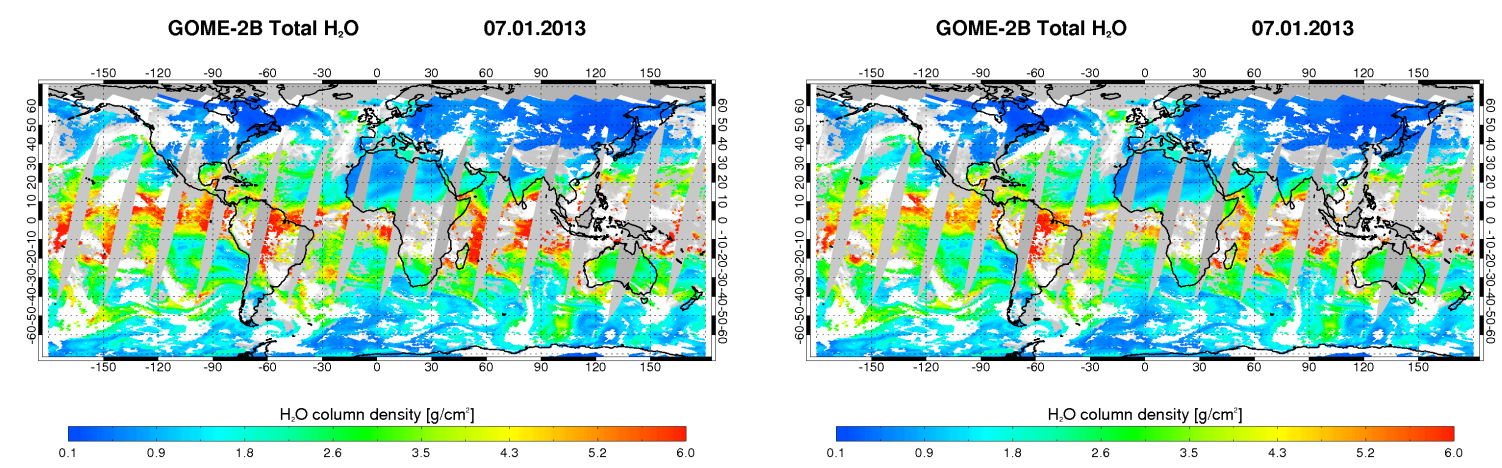

Figure 2. $\mathrm{H}_{2} \mathrm{O}$ total columns derived from GOME-2B measurements for the 7 January 2013 without the SAD correction (on the left) and using the SAD correction (on the right). Only cloud-screened data corresponding to solar zenith angles smaller than $87^{\circ}$ are shown.

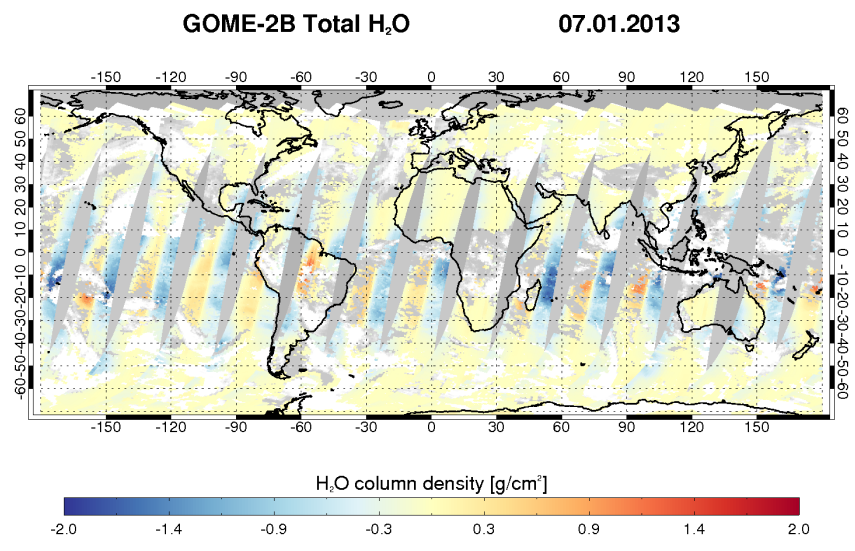

Figure 3. Difference between $\mathrm{H}_{2} \mathrm{O}$ total columns derived from GOME-2B measurements for the 7 January 2013 using the SAD correction and without the SAD correction.

fact that, when looking at the daily co-locations, we are comparing data from different parts of GOME-2A and GOME2B swaths (and thus different lines of sight). Using the data sets without SAD correction (left panel of Fig. 4), we can see that differences alternate between positive and negative values, depending on whether the east part of the GOME$2 \mathrm{~A}$ swath is collocated with the west part of the GOME2B swath or vice versa. This effect is reduced in the GDP 4.7 data sets (right panel of Fig. 4). There we can observe null bias (in green) in extended sub-tropical regions, such as continental northern Africa and Asia. The remaining differences in the tropics are mainly related to the presence of low clouds, the asymmetric cloud screening (due to the $\mathrm{O}_{2}$ cloud flag indicator, see Sect. 3.2) and low statistics (because of the smaller overlap region).

\subsection{Monthly GOME-2 comparison}

The global average monthly mean bias between GOME-2A and GOME-2B data sets for the period January 2013-June 2014 is shown in Fig. 5. The analysis is performed comparing gridded monthly mean data. From the 15 July 2013 GOME$2 \mathrm{~A}$ operates in tandem mode, and the overlapping area between the orbits of the two satellites is reduced. However, the mean bias values are consistent with the one retrieved in previous months. Averaging over the full time period, we find a small mean negative bias of $-0.006 \pm 0.018 \mathrm{~g} \mathrm{~cm}^{-2}$, while the biggest discrepancies are observed in January 2013 (mean bias of $-0.025 \mathrm{~g} \mathrm{~cm}^{-2}$ ). GOME-2B tends to produce slightly larger $\mathrm{H}_{2} \mathrm{O}$ total column values than GOME-2A, but not more than $1.25 \%$. The standard deviation for water vapour data is dominated by natural variability and is therefore quite large (see error bars in Fig. 5). Very similar results are obtained using only co-located data, since the GOME-2A and GOME-2B data sets are processed with the same algorithm and the same cloud screening criteria.

Studying the spatial distribution of the bias in January 2013, we observe that less than $3 \%$ of the locations present a bias bigger than $0.5 \mathrm{~g} \mathrm{~cm}^{-2}$ in absolute value. The mean difference between GOME-2A and GOME-2B $\mathrm{H}_{2} \mathrm{O}$ total columns is within the optimal accuracy threshold $(5 \%)$ specified in the O3M-SAF Service Specification Document (Hovila and Hassinen, 2013). This document presents the requirements for operational product and services of the EUMETSAT's O3M-SAF. The accuracy value is defined as the root mean square difference between the measurements and the reference data set. This shows that the GOME-2B $\mathrm{H}_{2} \mathrm{O}$ total column product can be used for scientific purposes to extend the GOME-type $\mathrm{H}_{2} \mathrm{O}$ time series.

To access the consistency between the two samples, we performed an orthogonal regression using gridded monthly GOME-2A and GOME-2B data. The grid cells used to bin the GOME- 2 measurements have an extent of $0.5^{\circ}$ latitude $\times 0.5^{\circ}$ longitude. Figure 6 shows the scatter plot of cloud-screened GOME-2A data against GOME-2B for January 2013 together with the histogram of the distribution of the differences GOME-2A - GOME-2B. The slope of the regression is very close to unity $(0.992)$ and the offset is very small and negative $\left(-0.009 \mathrm{~g} \mathrm{~cm}^{-2}\right)$, consistent with the mean bias results. 

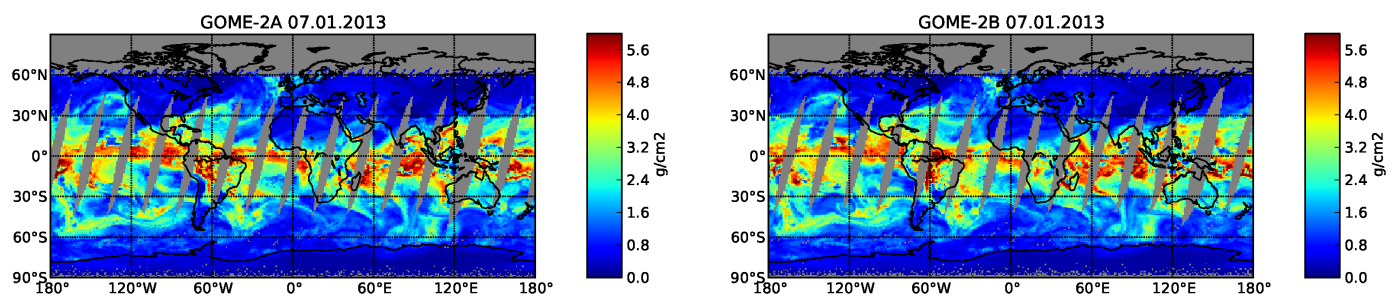

GOME-2A - GOME-2B $\quad 07.01 .2013$
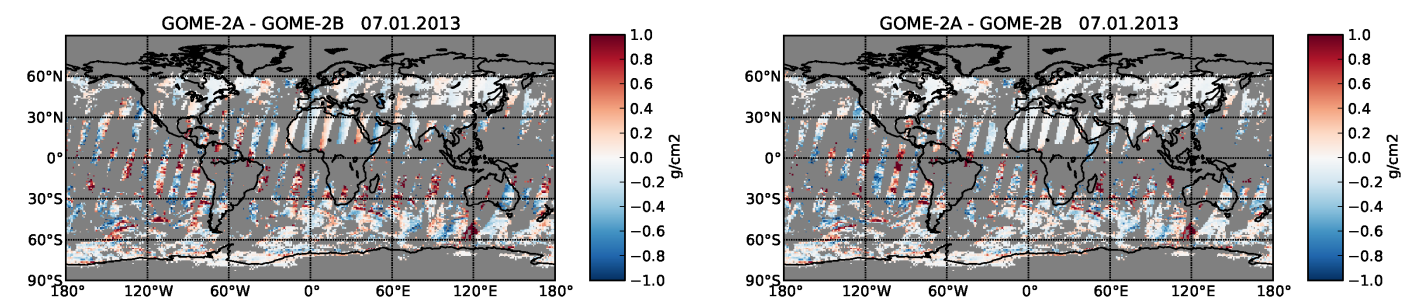

Figure 4. Top panels: daily averages of $\mathrm{H}_{2} \mathrm{O}$ total columns from GOME-2A and GOME-2B for the 7 January 2013 with SAD correction applied. Only data corresponding to solar zenith angles lower than $87^{\circ}$ are used. GOME-2A and GOME-2B measurements are separated by approximately $48 \mathrm{~min}$ in time. Bottom panels: geographical distribution of the differences between GOME-2A and GOME-2B total column water vapour for the 7 January 2013 when the SAD correction is applied to the two data sets (right panel, GDP 4.7) and without SAD correction (left panel, GDP 4.6). Cloud-free co-located measurements are shown in the plot.

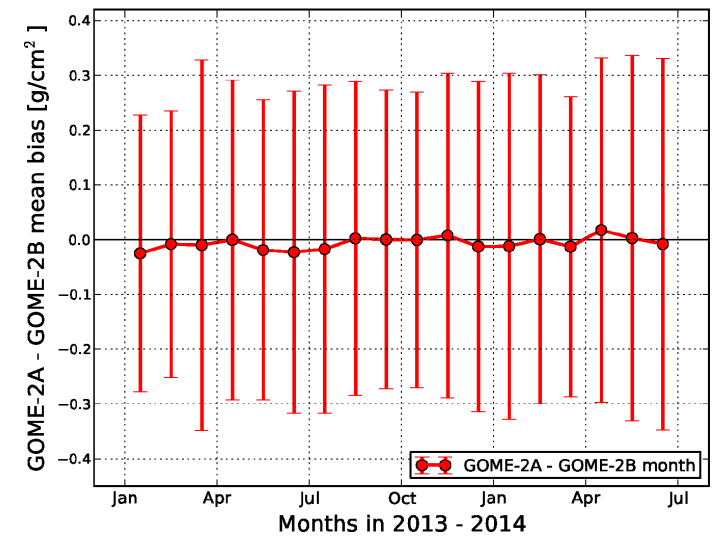

Figure 5. Global monthly mean $\mathrm{H}_{2} \mathrm{O}$ total column bias between GOME-2/MetOp-A and GOME-2/MetOp-B for the period January 2013-June 2014. The large error bars represent the standard deviation of the monthly averaged bias and are dominated by natural variability.

To investigate the differences between the GOME-2A and GOME-2B TCWV as a function of latitude, we have repeated the inter-comparison exercise for co-located (within $24 \mathrm{~h}$ ) measurements, with and without cloud mask, and we further computed the zonal averages for $2.5^{\circ}$ latitude intervals. Figure 7 shows the comparison of zonal TCWV values for January 2013 in two different cases: for (mostly) cloud-free measurements (left panel) and for all measurements (right panel). The points in the left panels of each plot represent the individual mean water vapour measurements as a function of latitude (red for GOME-2A, green for GOME$2 B)$. From these plots, we can infer that there is a very good agreement between GOME-2A and GOME-2B mea- surements for all latitudes. In order to examine more clearly the latitudinal variations, in the right panels of Fig. 7 we show the difference GOME-2B-GOME-2A $\mathrm{H}_{2} \mathrm{O}$ total column. The largest absolute deviations occur near the equator $\left(10^{\circ} \mathrm{N}-10^{\circ} \mathrm{S}\right)$. On average, at these locations the GOME-2B total columns are slightly larger than the GOME-2A columns (about 2-3\% larger in relative value), as inferred also from the scatter plots (Fig. 6). The relative difference is always positive, especially in the tropical area, which means that the GOME-2B data present a small wet bias with respect to GOME-2A. The maximum bias reaches $0.117 \mathrm{~g} \mathrm{~cm}^{-2}$ $(2.7 \%)$, and the mean bias is higher in the southern hemisphere than in the northern one. We can also notice that the scatter in the differences is generally bigger for cloud-free measurements than for unfiltered data. The smaller number of data points due to the cloud selection translates as a larger root mean square error (RMSE) in the former case (see Grossi et al., 2013).

\section{Comparison results and discussion}

To assess the quality of the satellite products, both the GOME-2A and the GOME-2B $\mathrm{H}_{2} \mathrm{O}$ total column product are compared to independent satellite observations and ECMWF ERA-Interim reanalysis data. Each of these data sets has its own advantages and disadvantages and therefore, from the different comparisons, we can study different properties of the GOME-2 data sets.

\subsection{Comparison data sets}

First, GOME-2A and GOME-2B measurements are compared with corresponding data from the European Centre for 

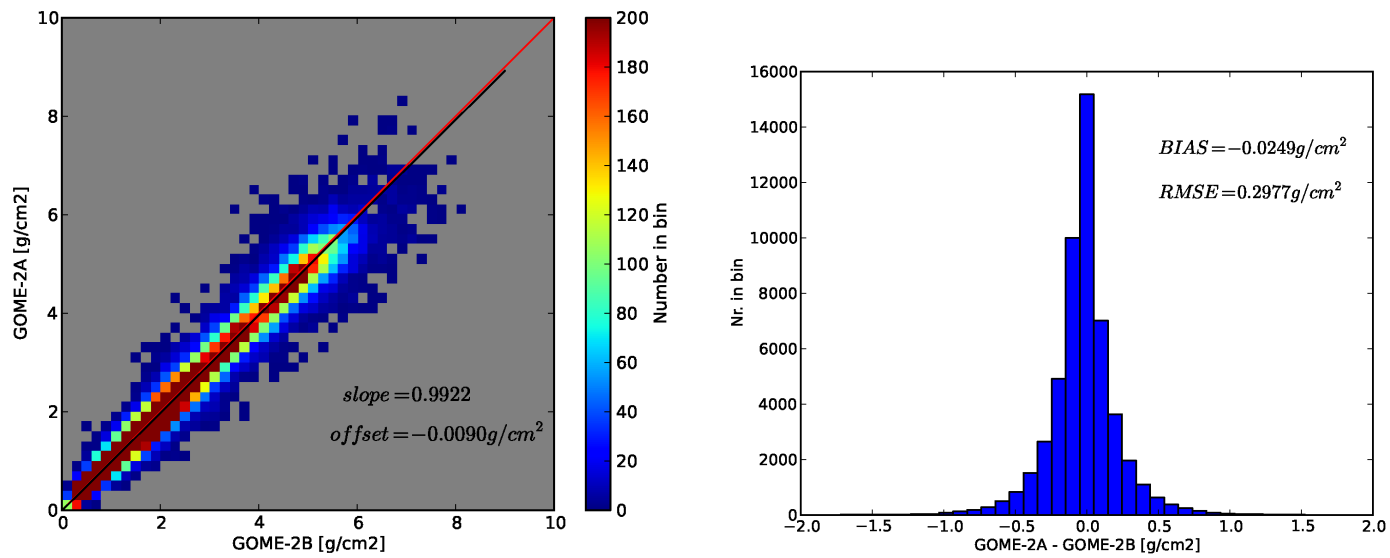

Figure 6. Left panel: scatter plot of GOME-2A monthly mean total columns against GOME-2B monthly mean total columns, for January 2013 and cloud-free sky. The slope of the orthogonal regression is 0.992 with an offset of $-0.009 \mathrm{~g} \mathrm{~cm}^{-2}$. Right panel: histogram of the difference GOME-2A - GOME-2B, for the points in the scatter plot. The mean bias is $-0.0249 \mathrm{~g} \mathrm{~cm}^{-2}$ with a root mean square error of $0.297 \mathrm{~g} \mathrm{~cm}^{-2}$ and a negative skewness.
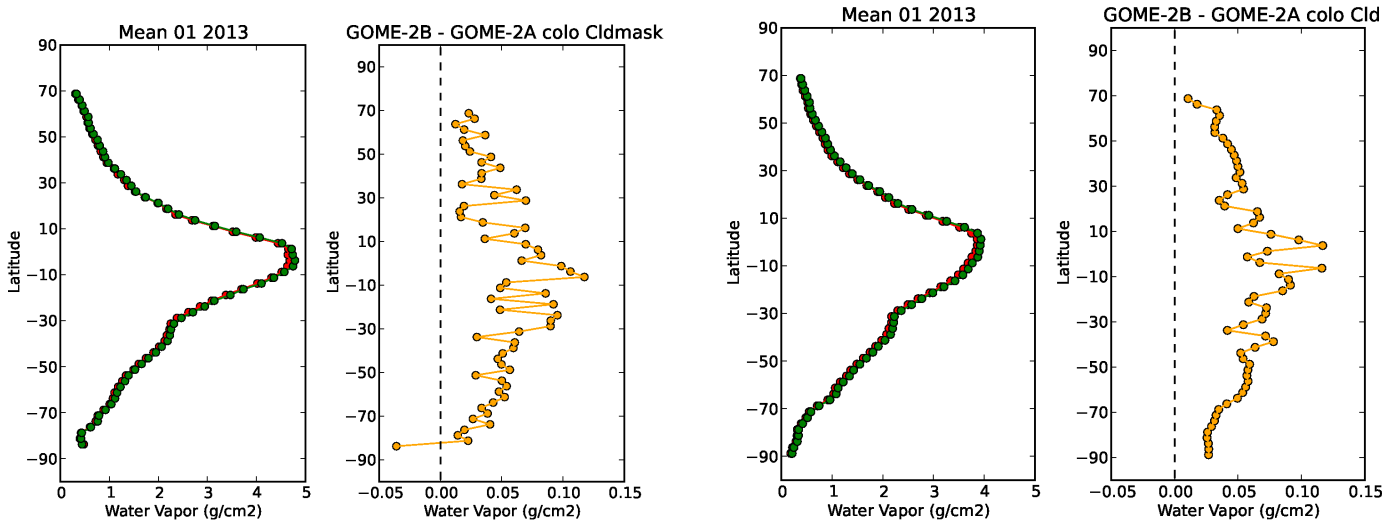

Figure 7. Zonal mean $\mathrm{H}_{2} \mathrm{O}$ total column from GOME-2A (red points) and from GOME-2B (green points) as a function of latitude for January 2013 and bias between GOME-2B and GOME-2A monthly averaged $\mathrm{H}_{2} \mathrm{O}$ total column. The results refer to daily co-located GOME-2A and GOME-2B measurements with cloud mask (left plot) and without cloud mask (right plot).

Medium Range Weather Forecasts (ECMWF). The $\mathrm{H}_{2} \mathrm{O}$ total column data used here are based on the ECMWF ERAInterim reanalysis data set (Dee et al., 2011a, b). ERAInterim is the latest global atmospheric reanalysis produced by ECMWF and provides a coherent record of the global atmospheric evolution constrained by the observations during the period of the reanalysis (1979-present). An advantage of using reanalysis data for the comparison is that they provide a global view that encompasses essential climate variables in a physically consistent framework. The results are produced with a sequential data assimilation scheme, in which available observations are combined with prior information from forecast models, in order to estimate the evolving state of atmospheric water vapour. Gridded data products include a large variety of three-hourly surface parameters, describing weather as well as ocean-wave and land-surface conditions, and six-hourly upper-air parameters covering the tro- posphere and stratosphere. The accuracy of the data assimilation scheme, however, will depend on the quality and availability of observations in the selected time frame. Large errors in reanalysis products can originate from the lack of observations, changes in the observing system and shortcomings in the assimilation model.

The improved atmospheric model and assimilation system used in ERA-Interim significantly reduces several of the inaccuracies exhibited by the previous ERA-40 reanalysis, such as too-strong precipitation over oceans from the early 1990s onwards and a too-strong Brewer-Dobson circulation in the stratosphere. Known key limitations of the ECMWF ERA-Interim data set are a very intense water cycling (precipitation, evaporation) over the oceans and positive biases in temperature and humidity (below $850 \mathrm{hPa}$ ) compared to radiosondes in the Arctic. 
In this study, we use model outputs between January 2007 and April 2014. We combine the ECMWF ERA-Interim forecast $12 \mathrm{~h}$ values produced from forecasts beginning at 00 and 12 coordinated universal time (UTC) to derive a daily mean $\mathrm{H}_{2} \mathrm{O}$ total column. Forecast data are produced by the forecast model, starting from an analysis, and are available at various forecast steps from the analysis date and time. It is important to note that, since the SSM/I and SSMIS temperature radiance observations have been assimilated into ERAInterim over ocean, the products are not completely independent from each other.

The second data set is based on passive microwave observations from the Special Sensor Microwave Imager Sounder (SSMIS) orbits of the F16 satellite. These data are produced by the remote sensing system and sponsored by the NASA earth science MEaSUREs DISCOVER projects (REMSS, http://www.ssmi.com/ssmi). The series of seven Special Sensor Microwave/Imager (SSM/I) have been in orbit since 1987 on various platforms, predominantly those of the Defense Meteorological Satellite Programs (DMSP) F-platforms, and now the SSM/I series has been replaced by a combined imager/sounder called SSMIS. In this study, we use SSMIS measurements of the F16 polar orbiting satellite between January 2007 and June 2014.

The SSMIS data products are generated using a unified algorithm to simultaneously retrieve ocean wind speed, atmospheric water vapour, cloud liquid water, and rain rate (Wentz, 1997). This algorithm is based on a physical model for the brightness temperature of the ocean and intervening atmosphere, and is the product of 20 years of refinements, improvements and verifications. Radiative transfer theory provides the relationship between the Earth's brightness temperature and the geophysical parameters (surface temperature, near-surface wind speed and vertically integrated cloud liquid water), which are used for the retrieval. TCWV data are available over ocean only and rely on independent calibration against radiosonde (Wentz, 2013). However, they also include TCWV for cloudy scenes, both day and night overpasses and span a very large time range.

The third sample we analyse relies on the GlobVapour combined SSM/I + MERIS TCWV Level 2 data set (Schröder et al., 2012b), derived within the ESA DUE GlobVapour project. Both products were processed independently and combined afterward to fit in daily and monthly files. The combined data set is based on TCWV retrievals from measurements in the microwave range taken by SSM/I (Fennig et al., 2012) over ocean, and measurements of the visible and near infrared by MERIS over land and coastal regions, to provide a global coverage. For the comparison with GOME-2 TCWV, we used gridded daily data, which have a spatial resolution of $0.5^{\circ} \times 0.5^{\circ}$ degrees, in the period January 2007December 2008 (SSM/I+MERIS products from the GlobVapour project are available only for the time frame 20032008).
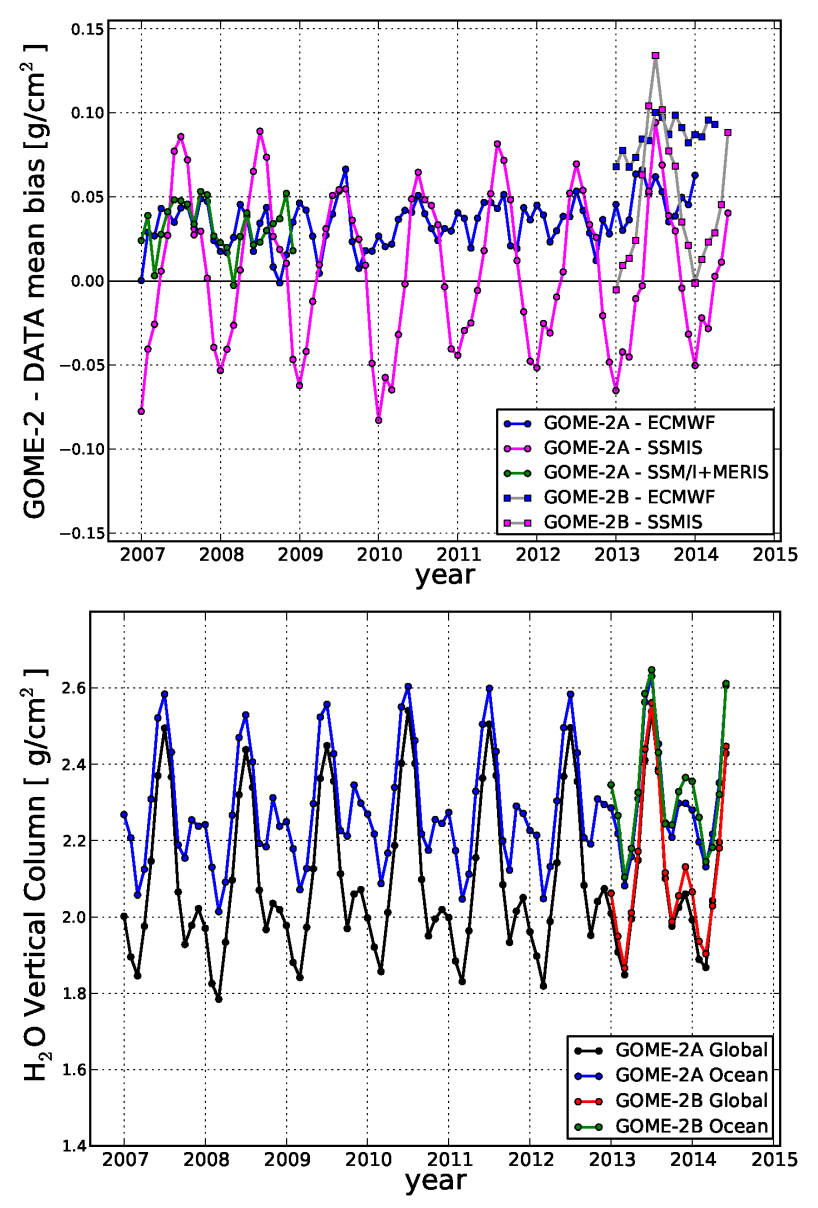

Figure 8. Top panel: global monthly mean bias between GOME2/MetOp-A and three independent TCWV data sets for the period January 2007-June 2014, depending on availability of the data. The comparison is performed against ECMWF ERA-Interim reanalysis (blue points), SSMIS F16 satellite (magenta points, only over ocean) and the combined SSM/I+MERIS data set (green points). Coloured squares and grey lines show the bias between the most recent GOME-2/MetOp-B observations and the ECMWF ERA-Interim and SSMIS data sets. Bottom panel: global monthly mean TCWV values for the GOME-2/MetOp-A and the GOME2/MetOp-B data sets. The time series are computed for all surfaces (global: land and ocean together) and only for ocean measurements.

The MERIS algorithm (Lindstrot et al., 2011) retrieves TCWV amounts for cloud-free scenes for daytime overpasses over land with a very good spatial resolution. As for GOME-2, the quality of the product is mainly determined by uncertainties in cloud detection. Since MERIS retrieves data only during daytime and at a fixed equator crossing time (10:00 a.m.), to provide a consistent data set, the SSM/I products were created from morning overpasses (descending path) of the F13 and F14 satellites. The DMSP F13 and F14 descending orbit cross the equator between 06:00 a.m. and 08:00 a.m. local time. In the framework of the GlobVapour project, an improved version of the Hamburg Ocean Atmo- 
sphere Parameters and Fluxes from Satellite Data (HOAPS) algorithm has been developed for the SSM/I TCWV retrieval (Phalippou, 1996; Deblonde, 2001). It is important to note that the SSMIS TCWV measurements from the REMSS are retrieved using a different algorithm. Finally, the bias between the SSM/I and MERIS data sets has been assessed by comparing the results of both retrievals over sun-glint areas, in order to assure a smooth transition from ocean to land and island sites (Schröder et al., 2012b).

\subsection{Mean bias time series}

All comparisons between GOME-2 TCWV measurements and the three data sets described above use the same gridding and filtering procedure in order to reduce sampling related issues. Daily water vapour measurements are first gridded on a regular $1.5^{\circ} \times 1.5^{\circ}$ spatial grid. Then, daily co-located data are used to compute the monthly mean bias between GOME2 and all the data sets analysed here (SSM/I+MERIS data are only available as gridded monthly and daily mean). The comparisons are performed for GOME- $2 \mathrm{H}_{2} \mathrm{O}$ total columns which are not flagged as cloud-contaminated on the Level 2 data product. Pixels flagged as cloudy are also removed on a daily basis from the data sets selected for the comparison.

Figure 8 (top panel) shows a time series of globally averaged total bias of the TCWV distribution between GOME$2 \mathrm{~A}$ and the comparison data sets for the time period January 2007-June 2014. Since January 2013 we have also computed the bias between the most recent GOME-2B results and the ECMWF ERA-Interim and SSMIS retrievals. The inter-comparison has been performed in such a way that positive and negative bias imply respectively larger and lower GOME-2 data. The agreement between GOME-2 data and the independent measurements considered here is very good for all comparisons: the mean bias for the full time series is very close to 0 , while the RMSE varies between 0.3 and $0.4 \mathrm{~g} \mathrm{~cm}^{-2}$ (see Table 2). The RMSE for the water vapour measurements is evaluated in the following way:

$\mathrm{RMSE}=\sqrt{\sum_{N}\left[\left(\Omega_{\mathrm{H}_{2} \mathrm{O}_{\mathrm{GOME}-2}}, 0-\Omega_{\mathrm{H}_{2} \mathrm{O}_{\mathrm{comp}}}, 0\right)^{2}\right] / N}$,

where $\left(\Omega_{\mathrm{H}_{2} \mathrm{O}_{\mathrm{GOME}-2}}, 0-\Omega_{\mathrm{H}_{2} \mathrm{O}_{\text {comp }}}, 0\right)^{2}$ is the difference between the GOME-2 sensor and the data set used for the comparison in each grid point. Because these deviations are squared before they are averaged, the RMSE gives a relatively high weight to large deviations. This means that the RMSE for the water vapour measurements is relatively high due to the high water vapour natural variations. The uncertainty margins provided for the bias and the RMSE statistics result from the spread of the bias and RMSE values in the time series. Since the GOME-2B total column data are typically larger than the GOME-2A data (see Sect. 4), the bias is also shifted towards higher values in this case. In the bottom panel of Fig. 8, we report the monthly averaged TCWV
Table 2. Bias and RMSE statistics. The computations refer to the average difference GOME- 2 data. The time period analysed is January 2007-April 2014 for the comparison GOME-2A ECMWF ERA-Interim, January 2007-June 2014 for GOME-2A - SSMIS and January 2007-December 2008 for GOME-2A SSM/I+MERIS. We use GOME-2B data starting from January 2013.

\begin{tabular}{l|rr}
\hline Data & Bias $\left[\mathrm{g} \mathrm{cm}^{-2}\right]$ & $\mathrm{RMSE}\left[\mathrm{g} \mathrm{cm}^{-2}\right]$ \\
\hline GOME-2A - ECMWF Global & $0.035 \pm 0.014$ & $0.305 \pm 0.053$ \\
GOME-2A - ECMWF Land & $-0.033 \pm 0.053$ & $0.366 \pm 0.068$ \\
GOME-2A - ECMWF Ocean & $0.073 \pm 0.034$ & $0.291 \pm 0.046$ \\
GOME-2A - SSMIS (Ocean only) & $0.006 \pm 0.045$ & $0.279 \pm 0.047$ \\
GOME-2A - SSM/I+MERIS Global & $0.032 \pm 0.014$ & $0.355 \pm 0.053$ \\
GOME-2A - SSM/I+MERIS Land & $-0.065 \pm 0.066$ & $0.435 \pm 0.046$ \\
GOME-2A - SSM/I+MERIS Ocean & $0.083 \pm 0.042$ & $0.341 \pm 0.055$ \\
GOME-2B - ECMWF Global & $0.086 \pm 0.010$ & $0.312 \pm 0.052$ \\
GOME-2B - ECMWF Land & $0.029 \pm 0.035$ & $0.344 \pm 0.048$ \\
GOME-2B - ECMWF Ocean & $0.122 \pm 0.028$ & $0.310 \pm 0.060$ \\
GOME-2B - SSMIS (Ocean only) & $0.047 \pm 0.040$ & $0.283 \pm 0.048$ \\
\hline
\end{tabular}

values for the GOME-2A and GOME-2B measurements in order to assist the interpretation of the bias results. The time series are computed for the ocean data set only and for all surfaces. We note that the $\mathrm{H}_{2} \mathrm{O}$ products exhibit a minimum during the northern hemispheric winter and a maximum in the summer months and that the TCWV values are typically larger over ocean surfaces.

As an exemplary time series, we further analyse the intercomparison between GOME-2A and SSMIS data (the magenta line and points in the top panel of Fig. 8). More than six years overlap between GOME-2A and SSMIS data provides a very good opportunity to investigate the seasonal dependence of the results. In this case, the bias is high in the northern hemisphere summer and low in the northern hemisphere winter, with the averaged TCWV for SSMIS being slightly higher than GOME-2 $\left(0.006 \mathrm{~g} \mathrm{~cm}^{-2}\right.$, see Table 2$)$. The monthly averaged bias ranges from $-0.083 \mathrm{~g} \mathrm{~cm}^{-2}$ in January 2010 to $0.094 \mathrm{~g} \mathrm{~cm}^{-2}$ in July 2013 . Since the microwave instruments can also measure the water vapour below clouds, we expect some residual difference between GOME-2 data (based on visible observations, where cloud blocks the radiation) and SSMIS data, which also deliver results in cloudy conditions. In Fig. 9, the global monthly mean bias between GOME- 2 and the three data sets is computed separately for land (top panel) and for ocean surfaces (bottom panel). Large seasonal variations in the distribution of the mean bias are also evident in the SSM/I+MERIS and ECMWF ERA-Interim comparisons, when analysing ocean surfaces alone. We can infer a seasonal cycle of the geographic distribution of the bias, which is probably caused, among other reasons, by the seasonality of cloud properties, as well as the variability of the geographic distribution of major cloud structures as the Intertropical Convergence Zone (ITCZ). 


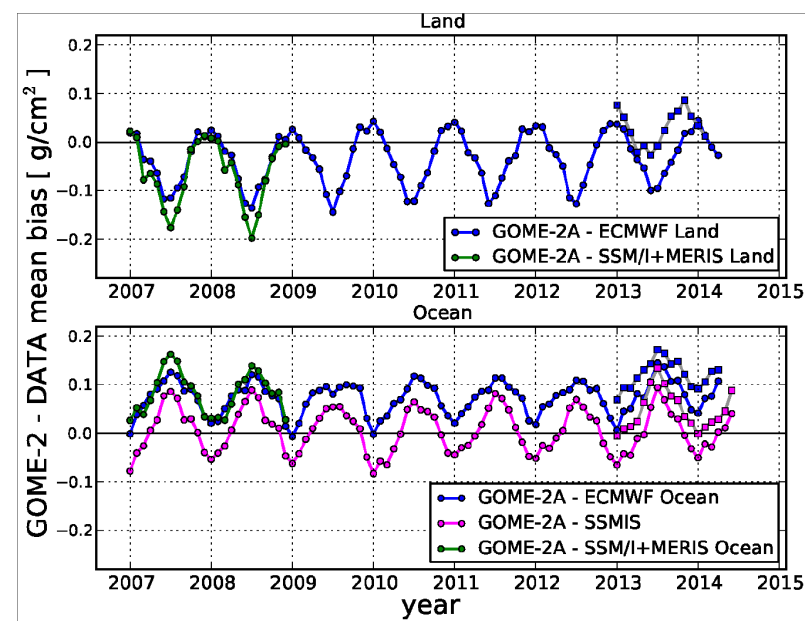

Figure 9. Global monthly mean bias between GOME-2/MetOpA and three independent TCWV data sets for the period January 2007-June 2014, depending on availability of the data. The bias is computed separately for land (top panel) and for ocean surfaces (bottom panel). Coloured squares and grey lines show the bias for the GOME-2/MetOp-B data set.

For the SSM/I + MERIS data set (green line and points in the top panel of Fig. 8), the seasonal behaviour is not as evident as for SSMIS, as a result of the different biases over land (MERIS) and sea (SSM/I). In general, the MERIS measurements present a wet bias with respect to the ECMWF ERA-Interim data over land, which might be partly caused by spectroscopic uncertainties in the MERIS algorithm, such as the description of the water vapour continuum (Lindstrot et al., 2012). When interpreting these results, we should keep in mind the limitations of the GOME-2 retrieval. Although, as discussed before, a specific advantage of the visible spectral region is that it is sensitive to the water vapour concentration close to the surface and that it has almost the same sensitivity over land and ocean, the accuracy of an individual observation is reduced for cloudy sky observations. In addition, the GOME-2 observations, which are made at 09:30 LT, cannot be representative of the daily, and therefore monthly, average $\mathrm{H}_{2} \mathrm{O}$ values in regions with a pronounced water vapour diurnal cycle. When repeating the comparison for ECMWF ERA-Interim and SSMIS outputs closest in time with GOME-2A measurements, differences in the mean bias of up to $0.02 \mathrm{~g} \mathrm{~cm}^{-2}$ are found. However, the global distribution of the affected areas is similar in both cases.

Finally, the ECMWF ERA-Interim data set (blue line and points in the top panel of Fig. 8) also shows a smaller oscillation around the mean bias against GOME-2A measurements, because of the compensating effect of having land and ocean retrievals. The amplitude of the winter-summer oscillation is $0.07 \mathrm{~g} \mathrm{~cm}^{-2}$ at most. The global mean bias is slightly positive $\left(0.035 \mathrm{~g} \mathrm{~cm}^{-2}\right)$ and very close to the SSM/I+MERIS result (mean bias of $0.032 \mathrm{~g} \mathrm{~cm}^{-2}$ ). As for the SSMIS and
SSM/I+MERIS comparison, we studied co-locations in order to derive conservative estimates for the precision of our water vapour retrieval. This is important to remove part of the bias introduced by the presence of TCWV data retrieved in cloudy conditions in microwave measurements and simulated data. As already discussed in Sect. 5.1, for the comparison we used the ECMWF ERA-Interim $12 \mathrm{~h}$ forecast based on 00:00 and 12:00 UTC analysis in order to have a more independent data set, since they include modelling. However, we have redone the same comparison using the analysis data set and obtained similar results (slightly larger bias, $0.039 \mathrm{~g} \mathrm{~cm}^{-2}$ instead of $0.035 \mathrm{~g} \mathrm{~cm}^{-2}$ ).

In order to interpret these results and to assess the observed biases and seasonal cycle, in the following sections we further discuss the method used and show the global distribution of the bias between GOME-2A and the three independent data sets for two exemplary months (February and August 2008).

\subsection{Comparison with ECMWF ERA-Interim TCWV model data}

The top plots of Fig. 10 present the monthly mean TCWV product in February 2008 obtained from daily co-locations of ECMWF ERA-Interim and GOME-2A data. We choose this month as representative of the water vapour distribution in the northern hemisphere winter season. In the bottom plots of Fig. 10, one can see the corresponding ECMWF ERAInterim and GOME-2A measurements in August 2008. In all panels, we can observe a high humidity in the tropics and low humidity at higher latitudes. Also, the movement of the Intertropical Convergence Zone with seasons is clearly visible from the shift of the high TCWV values in the tropics between February and August 2008. In both hemispheres, the TCWV distribution follows the seasonal cycle of the near surface temperature: the $\mathrm{H}_{2} \mathrm{O}$ total column has a maximum during the northern hemisphere summer, and a minimum in winter. Looking at the monthly mean differences between GOME-2A and ECMWF ERA-Interim, we can distinguish only a few regions with obvious discrepancies, e.g. the Amazon Basin and Central Africa in February 2008, or Southeast Asia in August 2008. Overall, we find similar spatial patterns in the $\mathrm{H}_{2} \mathrm{O}$ distribution in the ECMWF ERA-Interim and GOME-2A data sets. These results confirm that the GOME2 retrievals capture the overall spatial variability in the $\mathrm{H}_{2} \mathrm{O}$ total column values quite well both over ocean and land surfaces.

In order to quantify the discrepancies between ECMWF ERA-Interim data and GOME-2A TCWV retrieval, in Fig. 11 we show the spatial distribution of the bias for colocated and (mostly) cloud-free measurements. The mean bias between the two data sets is $0.017 \mathrm{~g} \mathrm{~cm}^{-2}$ in February and $0.044 \mathrm{~g} \mathrm{~cm}^{-2}$ in August 2008 .

In February, the bias is overall very low. Any deviation below the typical scatter of water vapour data of $0.4 \mathrm{~g} \mathrm{~cm}^{-2}$ 

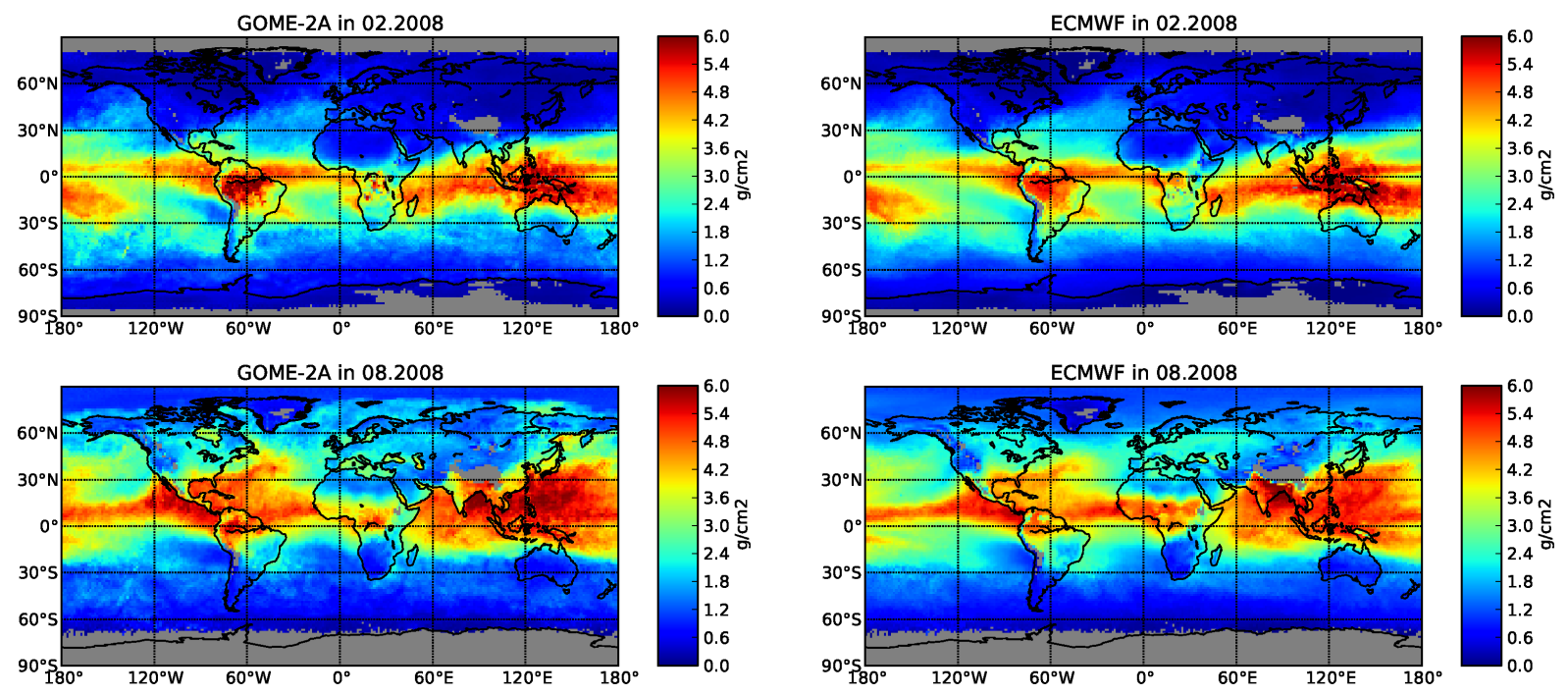

Figure 10. Monthly mean maps of total column water vapour from GOME-2A (on the left) and ECMWF ERA-Interim (on the right) co-located data for February 2008 (on the top) and August 2008 (on the bottom). Only cloud-screened data have been used.

(i.e. the light red and light blue areas in the plot) can be considered as a good agreement. GOME-2 exhibits a number of dry and wet spots in southern Africa and the South American Amazonian regions, not visible in the ECMWF ERA-Interim product, which are probably related to the very low number of co-locations in these regions due to cloud screening, typically less than eight measurements. Also, the problems of the ECMWF ERA-Interim data cannot be excluded, since remote regions may present larger errors due to paucity of observational information in the reanalyses, such as shown in Dee and Uppala (2009) for locations at latitudes greater than $70^{\circ}$ north. The differences over ocean, e.g. along the ITCZ and the Pacific Warm Pool region, on the other hand, might be caused by the rather high cloud tops in these regions, leading to low measured AMF and consequently to rather high $\mathrm{H}_{2} \mathrm{O}$ total columns. Even though we consider only grid boxes without severe cloud cover on a daily basis, some cloud effects are still present.

Relative large differences between GOME-2A and ECMWF ERA-Interim data can be seen in August 2008. For example, in summer 2008, the humidity in Central Africa is much lower in the GOME-2 data than that estimated in the ECMWF ERA-Interim data (absolute and relative differences larger than $-1 \mathrm{~g} \mathrm{~cm}^{-2}$ and $20 \%$, respectively). A negative bias can be observed in the region from India to the east coast of China and reaches values between -1.5 and $-2.1 \mathrm{~g} \mathrm{~cm}^{-2}$ in the northern part of the Indian Subcontinent. Looking at the lower panel of Fig. 11, we note that the underestimation (blue regions denote negative bias) is located in land areas with a very high humidity in the northern hemisphere summer months. From a correlation analysis, we found that the bias between GOME-2A and ECMWF ERA-Interim data over land areas decreases (larger negative values) with increasing humidity. This is consistent with the results of the validation against ground-based measurements (Kalakoski et al., 2014).

Dry bias is also observed in arid areas, such as southern regions of the Sahara desert, the coast of Somalia, the Arabian Desert in the Arabian Peninsula and the Thar desert in the north-western part of the Indian Subcontinent. Regions with relatively high surface albedo values (in the range 0.3-0.5) which present dry bias include northern Africa, the Arabian Peninsula, India and parts of East Asia and Central America. A possible explanation for the discrepancies is that, because of absorbing aerosols over deserts, the surface albedo we measure there is lower than the real value and, therefore, we underestimate the water vapour content (Fournier et al., 2006). In the future, we plan to further study the effect of the surface albedo database on the water vapour retrieval and refine this choice. However, we should keep in mind that the determination of the "real" surface albedo over desert regions is still a field of discussion, because of the uplifting of large amounts of dust, which lower the reflectivity (Herman et al., 1997; Torres et al., 1998). Finally, we observe a larger scatter in northern latitude ocean areas. The atmospheric transport or motion coupled to strong spatial gradients is one of the possible origins of this bias.

\subsection{Comparison with SSMIS TCWV observations}

Figure 12 shows the global monthly bias between GOME2A and SSMIS observations in February and August 2008. The land regions are masked in the comparison, because the SSMIS data set is available only over ocean scenes, but microwave sensors can also retrieve TCWV in the presence of clouds and for nighttime satellite overpasses. We used outputs from the ascending and descending F16 orbit from the 


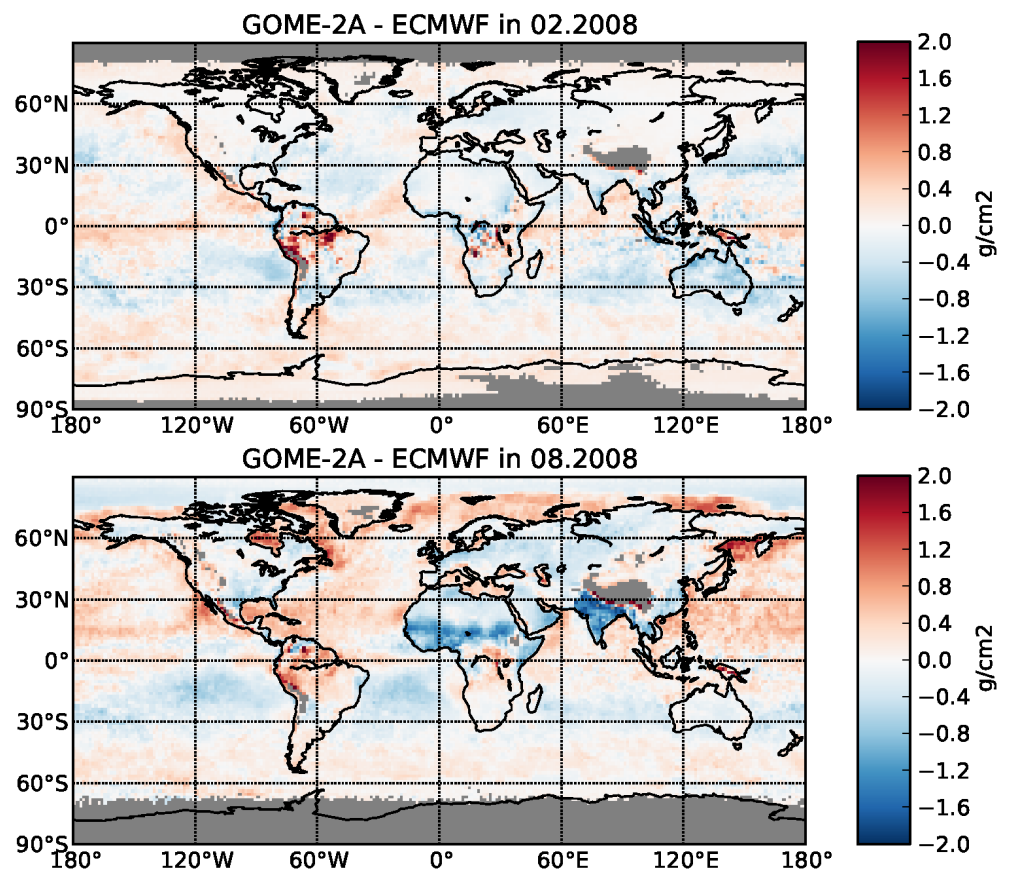

Figure 11. Geographical distribution of the differences between GOME-2A and ECMWF ERA-Interim total column water vapour in February 2008 (top panel) and August 2008 (bottom panel). Only cloud-screened co-located data have been used.

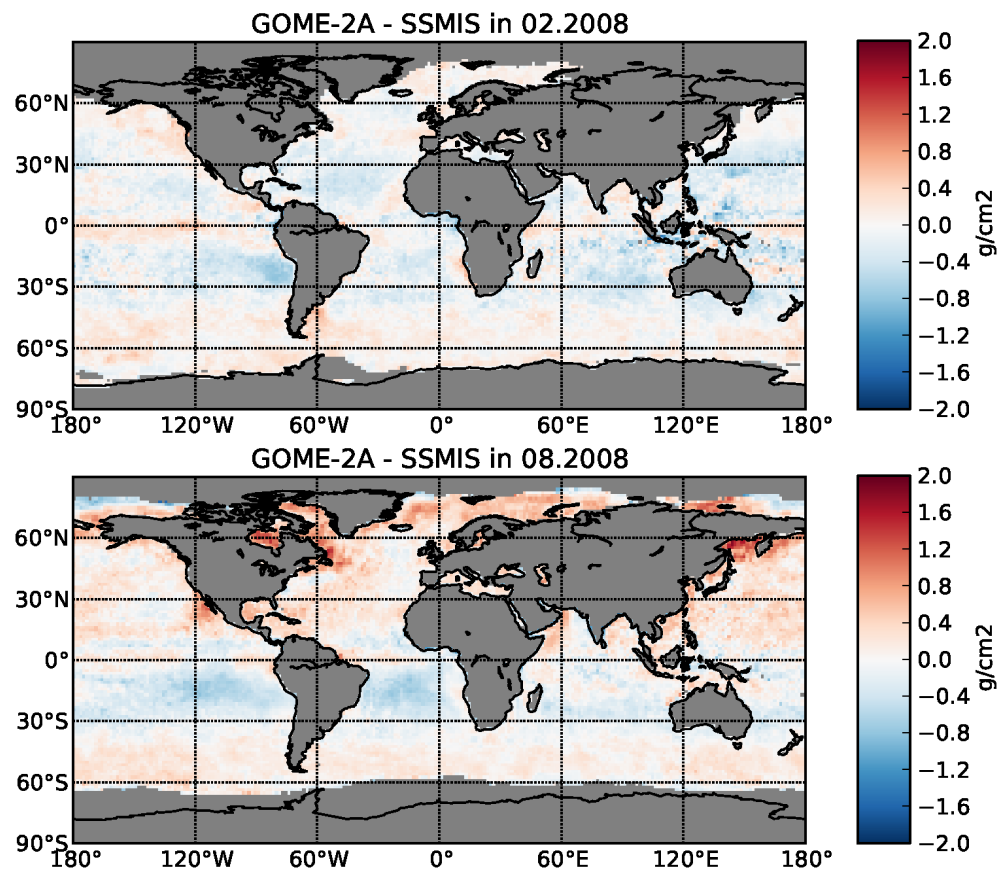

Figure 12. Geographical distribution of the differences between GOME-2A and SSMIS total column water vapour in February 2008 (top panel) and August 2008 (bottom panel). Only cloud-screened co-located data have been used. 


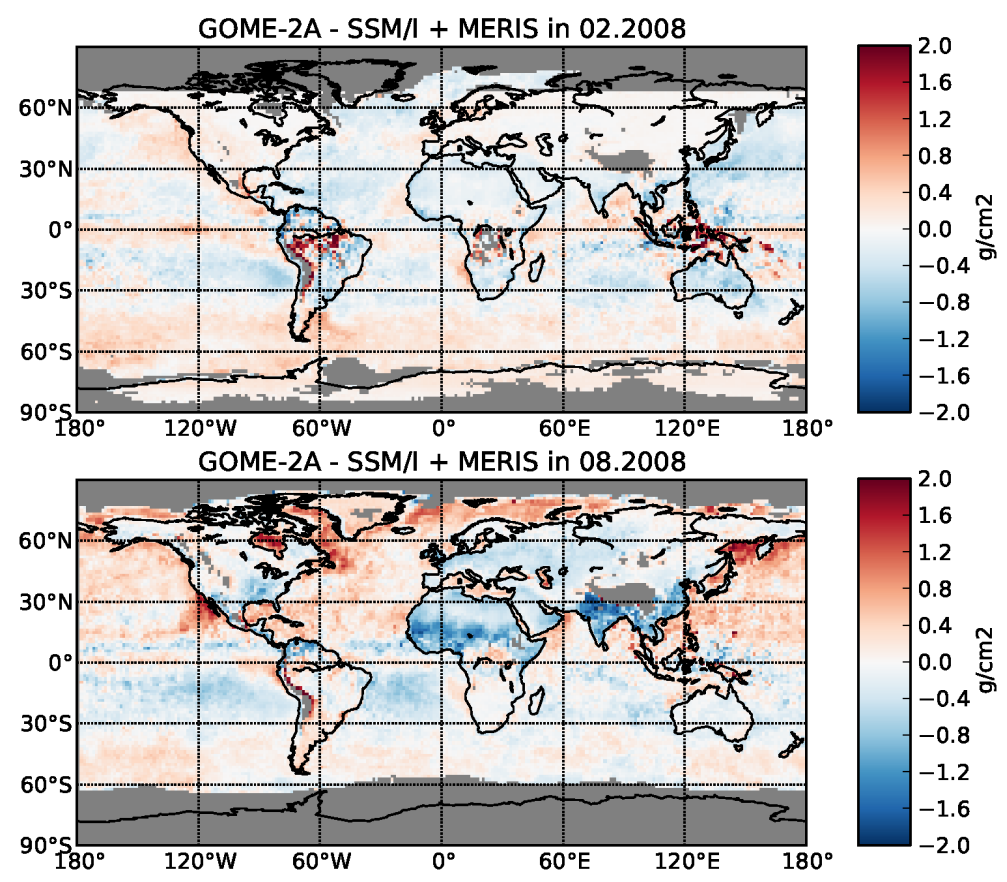

Figure 13. Geographical distribution of the differences between GOME-2A and the combined SSM/I+MERIS total column water vapour data set in February 2008 (top panel) and August 2008 (bottom panel). Only cloud-screened co-located data have been used.

daily binary SSMIS data files in order to compute gridded daily mean data used for co-locations. Ascending local equator crossing time is 16:39 LT as of 16 October 2014, and descending time 04:39 LT. If we evaluate the bias between GOME-2 and SSMIS from monthly mean data, we would find a larger and negative bias because of the cloud influence. Thus, as for ECMWF ERA-Interim data, we select only daily co-locations and we reject the SSMIS data if the corresponding GOME-2 measurement is contaminated by clouds (applying the cloud flag selection described in Sect. 3.1). This selection minimizes the effect of temporal change and cloud contamination in the GOME-2 vs. SSMIS comparison. The number of co-locations is further reduced since the TCWV retrieval is not possible in situations with high precipitation or near land areas $(<25 \mathrm{~km})$.

In the data from February 2008, a small negative mean bias between GOME-2A and SSMIS $\left(-0.041 \mathrm{~g} \mathrm{~cm}^{-2}\right)$ is derived (see Fig. 8). Looking at the top panel of Fig. 12, we observe very small discrepancies for most ocean regions, with the exception of some coastal areas, where the bias reaches values on the order of $\pm 0.5 \mathrm{~g} \mathrm{~cm}^{-2}$. We retrieve a larger mean bias of about $0.074 \mathrm{~g} \mathrm{~cm}^{-2}$ in August 2008 (bottom panel of Fig. 12). A large positive bias is clearly visible in regions at high latitude, in particular the northern areas of the Atlantic and Pacific Ocean (bias values typically between 0.5 and $0.9 \mathrm{~g} \mathrm{~cm}^{-2}$ ) and is the dominating cause for the pronounced seasonal component in the SSMIS against GOME$2 \mathrm{~A}$ comparison results. These differences were also observed in the comparison with the ECMWF ERA-Interim data set (see Fig. 11) and are thus likely related to the GOME-2 measurements. Analysing the cloud parameters retrieved by GOME-2A for daily co-located measurements, we found that larger biases are typically associated with higher cloud fractions $(>0.5)$. No clear dependence of the bias on the cloud top height parameter is found, in contrast to the validation between radiosonde and SCIAMACHY data retrieved with the AMC-DOAS algorithm (du Piesanie et al., 2013).

Among the limitations of the SSMIS data, we should mention that the model and algorithm for the retrieval are calibrated using an in situ database containing overpasses of buoys and radiosonde sites. The accuracy of the TCWV product depends on the quality of these observations, and not all the regions and atmospheric situations may be equally represented in the training data set (Andersson et al., 2010). It was already shown that the maximum bias between satellite and ship data (of about $0.25 \mathrm{~g} \mathrm{~kg}^{-1}$; average bias of approximately $2 \%$ ) was found precisely over the North Atlantic Ocean during the summer season (Bentamy et al., 2003). Also, depending on location and season, systematic differences of atmospheric humidity of about $1 \%$ for $1 \mathrm{~h}$ time difference between the GOME-2A and SSMIS retrieval might be expected (Kalakoski et al., 2011), and in regions with a particularly high diurnal variability, as for instance over the North Atlantic, they can be even larger. 


\subsection{Comparison with the SSM/I+MERIS TCWV data set}

The comparison of the GOME-2 product with the combined SSM/I+MERIS GlobVapour data set for February and August 2008 is shown in Fig. 13. The agreement between GlobVapour data and GOME-2 measurements seems to be somewhat better over land than over ocean. The difference plot in February 2008 (top panel) is quite noisy and the GOME2 data over ocean tend to be lower than the corresponding SSM/I+MERIS monthly mean. This is in line with the results we obtain from the comparison with SSMIS data for the same month. An interesting ocean area is the one west of Central America and Colombia, and the coast of Africa, where we have positive differences, not seen in the ECMWF ERA-Interim comparison (Sect. 5.3), and associated with higher cloud-top albedo values.

Over the continents, the agreement between both data sets is generally very good, as seen in the comparison with ECMWF ERA-Interim data. A specific advantage of the MERIS instrument is the very high spatial resolution $\left(1 \times 1.2 \mathrm{~km}^{2}\right.$ in the reduced resolution mode) and therefore the ability to retrieve sharp gradients in water vapour abundance with great accuracy. We can observe extended regions with very small biases, close to zero, especially in Asia and Africa. Exceptions are found in some specific small areas where GOME-2 columns are higher than the MERIS values. A slight overestimation of water vapour content by GOME2 (or underestimation by SSM/I + MERIS) seems to occur preferably over Europe and the western part of North America. Major differences are located in coastal areas, where neither SSM/I, nor MERIS provide accurate estimates. For MERIS, this is due to the weak reflectance of the ocean in the near infrared and on the resulting uncertainties introduced by the unknown contribution of aerosol scattering and absorption, while SSM/I measurements cannot be used in case of relative large footprint contaminated by land. Significant differences over European and North American coasts (e.g. in the southern part of Sweden, along the coasts of the Baltic Sea) are not seen in the comparison with ECMWF ERAInterim data. Thus, it is not clear whether the discrepancies observed at high latitudes result from difficulties with the retrieval over ice-covered regions (Schröder et al., 2012d). Finally, as for GOME-2, the quality of the MERIS TCWV retrieval algorithm strongly depends on the reliability of the cloud screening procedure, and we can expect a weak dry bias where the cloud detections fail.

The average bias between GOME-2A and SSM/I+MERIS in February 2008 is $0.02 \mathrm{~g} \mathrm{~cm}^{-2}$, while we found a slightly larger positive bias $\left(0.03 \mathrm{~g} \mathrm{~cm}^{-2}\right)$ in August 2008. As shown in Fig. 9, for this data set we can observe a systematic variation in the bias between winter and summer months over land and ocean. The same effects was also observed in Schröder et al. (2012c), when comparing the SSM/I+MERIS GlobVapour product with the homogenized
GOME/SCIAMACHY/GOME-2 time series. In the northern hemisphere winter months, mostly negative bias over sea and positive bias over land is observed. In the northern hemisphere summer months (see bottom panel of Fig. 13), on the other hand, the MERIS data tend to be more wet than the corresponding GOME-2A data, with a large bias (between -0.4 and $-2.2 \mathrm{~g} \mathrm{~cm}^{-2}$ ) in Southeast Asia, Central Africa and part of Saudi Arabia and North America. In the aforementioned comparison by Schröder et al. (2012c), dry bias features located over northern Africa, part of the Arabian Peninsula and the north-western part of the Indian Subcontinent were observed in July 2006 and July 2007. Similar patterns were also reported in the comparison with the ECMWF ERA-Interim data set, hinting at problems in the GOME-2 data. About $7.5 \%$ of the grid boxes present a bias larger than $0.5 \mathrm{~g} \mathrm{~cm}^{-2}$ (only $4.4 \%$ in the comparison with ECMWF ERA-Interim). The discrepancies are inversely correlated with GOME-2A regions with high surface albedo $(0.3-0.5)$ or high humidity values. In previous studies (Lindstrot at al., 2012), a potential underestimation of the absorption at $900 \mathrm{~nm}$ was identified as a possible source of a wet bias in the MERIS data set.

An orthogonal regression analysis of the scatter between GOME-2 and SSM/I+MERIS monthly mean measurements (as opposed to co-located data sets presented before) showed a good correlation between both data sets. We found an almost ideal slope of 0.981 and 1.006 in February and August 2008, respectively. Also, the offset is very small, especially for the summer comparison $\left(-4 \times 10^{-4} \mathrm{~g} \mathrm{~cm}^{-2}\right)$. Although the majority of data shows very good correlation, SSM/I+MERIS mid-value water columns (i.e. $1-3 \mathrm{~g} \mathrm{~cm}^{-2}$ ) are often lower than the GOME co-located products. The average mean bias for February in this case is negative $\left(-0.021 \mathrm{~g} \mathrm{~cm}^{-2}\right)$. Since microwave instruments can also retrieve the water vapour in cloudy conditions, comparing the GOME-2 measurements with the SSM/I on a monthly base, means also using SSM/I observations with large cloud cover. If we do a daily co-location, on the other hand, the results of the two satellites are closer, because in this case we reject all SSM/I measurements in regions flagged as cloudy by the GOME-2 instruments. In August 2008, the largest scatter occurs for values around $2 \mathrm{~g} \mathrm{~cm}^{-2}$, which are observed in the transition zone between tropics and extra-tropics, where large natural variability is observed.

\section{Summary and conclusions}

In this paper, we present an algorithm for the retrieval of water vapour total columns from the Global Ozone Monitoring Experiment-2 (GOME-2) on board the MetOp-A and MetOp-B platforms, and we perform an analysis and evaluation of this data set against independent satellite observations and the latest ECMWF ERA-Interim reanalysis data.

The operational GOME-2 TCWV product used in this study has been developed in the framework of EUMETSAT's 
O3M-SAF project in co-operation with MPI-C Mainz and DLR Oberpfaffenhofen, and generated using the UPAS environment and the GDP 4.7 algorithm. The retrieval algorithm is based on a classical DOAS method to obtain the trace gas slant column. Subsequently, the $\mathrm{H}_{2} \mathrm{O}$ total column is derived, making use of the simultaneously measured $\mathrm{O}_{2}$ absorption and radiative transfer calculations. This procedure is robust (it provides similar sensitivity over land and ocean), very fast and, in contrast to other satellite retrieval methods (as from TOVS, from SSM/I and SSMIS microwave observations and from GPS TCWV measurements), is independent from a priori assumptions on atmospheric properties.

In GDP 4.7, the quality of the GOME-2 $\mathrm{H}_{2} \mathrm{O}$ total column has been enhanced with respect to two major aspects: we improve the cloud selection criteria used in the retrieval algorithm, and we eliminate the dependency of the data set on the viewing angle conditions by applying a distinct empirical correction for land and ocean surfaces, both to GOME2A and GOME-2B measurements. We present exemplary results from about one and a half year measurements of the new GOME-2B instrument, launched on 17 October 2012, and an inter-comparison with the GOME-2A data for the overlap period. We found that the GOME-2B water vapour total columns are only slightly wetter than the GOME-2A measurements and present a small, positive bias of about $0.006 \mathrm{~g} \mathrm{~cm}^{-2}$ (less than $1 \%$ ), when averaging all the results from December 2012 to June 2014. Latitudinal averaged differences can be as large as $0.117 \mathrm{~g} \mathrm{~cm}^{-2}$ at low latitudes, since the orbits of the GOME-2A and the GOME-2B sensors have the smallest overlap in the tropical regions.

TCWV estimates from the GOME-2A and GOME-2B instruments are collocated and compared with SSMIS satellite F16 measurements and with ECMWF ERA-Interim model data during the full period January 2007-June 2014. Comparisons against a combined SSM/I + MERIS data set (as developed in the framework of the ESA DUE GlobVapour project) in 2007 and 2008 conclude our analysis.

Within our study, a surprisingly good agreement between GOME-2 type instruments and the three independent data sets analysed here is found, with a mean bias within $\pm 0.035 \mathrm{~g} \mathrm{~cm}^{-2}$ for the time interval January 2007-June 2014. As a reference value, the bias obtained by Kalakoski et al. (2011), comparing the GOME-2 TCWV data produced using an earlier algorithm version (GDP 4.5) with $\mathrm{SSM} / \mathrm{I}$ data, was typically between 0.17 and $0.25 \mathrm{~g} \mathrm{~cm}^{-2}$ for monthly global averages. While the annual variability over land and coastal areas is low, over ocean we observe a clear seasonal cycle with the highest values during the northern hemisphere summer. Slightly lower than in summer, and negative biases are found in the northern hemisphere winter months. These variations can mainly be related to the impact of clouds on the accuracy of the GOME-2 observations and to the different sampling statistics of the instruments.

Collocated GOME-2A data present a mean bias of $0.017 \mathrm{~g} \mathrm{~cm}^{-2}(0.4 \%)$ and $0.044(1.1 \%)$ with TCWV data from ECMWF ERA-Interim in February and August 2008, respectively. In August 2008, the comparison between the GOME observations and the SSMIS F16 satellite measurements yields an average bias of $0.074 \mathrm{~g} \mathrm{~cm}^{-2}$, and the differences in TCWV measured by the two systems is possibly dominated by residual cloud effects and the diurnal variability of the water vapour data over the North Atlantic Ocean. Global monthly averaged differences between the combined SSM/I+MERIS data sets and GOME-2 data are distributed between 0.0 and $0.05 \mathrm{~g} \mathrm{~cm}^{-2}$. GOME-2A data are typically drier than MERIS data over land areas with high humidity or a relatively large surface albedo (bias values between -0.4 and $-2.2 \mathrm{~g} \mathrm{~cm}^{-2}$ ), a circumstance which may indicate an influence of the surface albedo correction in the AMF calculation. Finally, GOME-2B measurements are in general biased high compared to the other water vapour data set. However, this discrepancy might be corrected to first order based on the results of the comparison with the GOME-2A data.

Recently, Kalakoski et al. (2014) performed a global validation of the GOME-2A and GOME-2B TCWV product presented in this study using radiosonde data from the IGRA archive and GPS data from the COSMIC/SuomiNet network. Overall, they found a good general agreement between GOME-2 and ground-based measurements. In their study, they observed small dry median differences against radiosondes (GOME-2A: $-2.7 \%$, GOME-2B: $-0.3 \%$ ) and small wet median differences against GPS data (GOME-2A: $4.9 \%$, GOME-2B: $3.2 \%$ ). Dry bias was observed especially over land in the northern hemisphere (co-locations over northern Africa and India showed generally a negative bias), while wet bias was found preeminently over ocean and in coastal areas. Consistent with our results, they remarked that pronounced negative biases are correlated with high $\mathrm{H}_{2} \mathrm{O}$ values $\left(>5 \mathrm{~g} \mathrm{~cm}^{-2}\right)$ and with high surface albedo $(>0.3)$.

GOME-2/MetOp-A and GOME-2/MetOp-B TCWV obtained with the GDP 4.7 algorithm continues the GOME and SCIAMACHY time series started in 1995. With the launch of the new GOME-2/MetOp-C instrument in 2018, the GOMEtype data record will be further extended to cover a period of at least 25 years of water vapour measurements. This unique data set has now reached high accuracy and stability and is expected to provide important information on long-term changes in our atmosphere.

Acknowledgements. Development of the GOME-2 water vapour products and their validation has been funded by the O3M-SAF project with EUMETSAT and national contributions. The authors thank the DFD colleagues S. Kiemle, K. H. Seitz, T. Padsuren and M. Schwinger, who are responsible for day-to-day operations of the O3M-SAF facility at DLR. We thank EUMETSAT for the ground segment interfacing work with the O3M-SAF systems and for the provision of GOME-2 Level 1 products.

The service charges for this open-access publication have been covered by a research centre of the 
Helmholtz Association.

Edited by: P. Stammes

\section{References}

Andersson, A., Fennig, K., Klepp, C., Bakan, S., Graß1, H., and Schulz, J.: The Hamburg Ocean Atmosphere Parameters and Fluxes from Satellite Data - HOAPS-3, Earth Syst. Sci. Data, 2, 215-234, doi:10.5194/essd-2-215-2010, 2010.

Antón, M., Loyola, D., Román, R., and Vömel, H.: Validation of GOME-2/MetOp-A total water vapour column using reference radiosonde data from GRUAN network, Atmos. Meas. Tech. Discuss., 7, 9573-9601, doi:10.5194/amtd-7-9573-2014, 2014.

Bauer, P. and P. Schlüssel: Rainfall, total water, ice water, and water vapour over sea from polarized microwave simulations and Special Sensor Microwave/Imager data, J. Geophys. Res., 98, 20737-20759, 1993.

Bentamy, A., Katsaros, K. B., Mestas-Nunez, A. M., Drennan, W. M., Forde, B. E., and Roquet, H.: Satellite estimates of wind speed and latent heat flux over the global oceans, J. Climate, 16, 637-655, 2003.

Bevis, M., Businger, S., Herring, T. A., Rocken, C., Anthes, R. A., and Ware, R. H.: GPS meteorology: Remote sensing of atmospheric water-vapor using the Global Positioning System, J. Geophys. Res., 97,15, 787-15,801, 1992.

Bevis, M., Businger, S., Chiswell, S., Herring, T. A., Anthes, R. A., Rocken, C., and Ware, R. H.: GPS meteorology: Mapping zenith wet delays onto precipitable water, J. Appl. Meteorol., 33, 379386, 1994

Bovensmann, H., Burrows, J. P., Buchwitz, M., Frerick, J., Noël, S., Rozanov, V. V., Chance K. V., and Goede, A. H. P.: SCIAMACHY - Mission objectives and measurement modes, J. Atmos. Sci., 56, 127-150, 1999.

Burrows, J. P., Weber, M., Buchwitz, M., Rozanov, V., LadstätterWeißenmayer, A., Richter, A., de Beek, R., Hoogen, R., Bramstedt, K., Eichmann, K.-U., Eisinger, M., and Perner, D.: The Global Ozone Monitoring Experiment (GOME): Mission Concept and First Scientific Results, J. Atmos. Sci., 56, 151-175, 1999.

Callies, J., Corpaccioli, E., Eisinger, M., Hahne, A., and Lefebvre, A.: GOME-2 - MetOp's Second Generation Sensor for Operational Ozone Monitoring, ESA Bulletin, No. 102, 2000.

Casadio, S., Zehner, C., Piscane, G., and Putz, E.: Emperical Retrieval of Atmospheric Airmass factor (ERA) for the Measurement of Water Vapor Vertical Content using GOME Data, Geophys. Res. Lett. 27, 1483-1486, 2000.

Chaboureau, J., Alain, C., and Nolle, A. S.: Remote sensing of the vertical distribution of atmospheric water vapour from the TOVS observations: Method and validation, J. Geophys. Res.-Atmos., (1984-2012), 103, 8743-8752, 1998.

Clerbaux, C., Boynard, A., Clarisse, L., George, M., Hadji-Lazaro, J., Herbin, H., Hurtmans, D., Pommier, M., Razavi, A., Turquety, S., Wespes, C., and Coheur, P.-F.: Monitoring of atmospheric composition using the thermal infrared IASI/MetOp sounder, Atmos. Chem. Phys., 9, 6041-6054, doi:10.5194/acp-9-6041-2009, 2009.
Cox, C. and W. H. Munk: Measurements of the roughness of the sea surface from photographs of the sun's glitter, J. Opt. Soc. Am., 44, 838-850, 1954.

Dai, A., Wang, J., Ware, R. H., and Hove, T. V.: Diurnal variation in water vapour over North America and its implications for sampling errors in radiosonde humidity, J. Geophys. Res., 107, 11.111.14, doi:10.1029/2001JD000642, 2002.

Deblonde G.: NWP SAF User's Guide: Standalone 1D-var scheme for the SSM/I, SSMIS and AMSU, NWPSAF-MO-UD-001 Version 1.0, 22 August, 2001.

Dee, D. P., Uppala, S. M., Simmons, A. J., Berrisford, P., Poli, P., Kobayashi, S., Andrae, U., Balmaseda, M. A., Balsamo, G., Bauer, P., Bechtold, P., Beljaars, A. C. M., van de Berg, L., Bidlot, J., Bormann, N., Delsol, C., Dragani, R., Fuentes, M., Geer, A. J., Haimberger, L., Healy, S. B., Hersbach, H., Hólm, E. V., Isaksen, L., Kållberg, P., Köhler, M., Matricardi, M., McNally, A. P., Monge-Sanz, B. M., Morcrette, J. J., Park, B. K., Peubey, C., de Rosnay, P., Tavolato, C., Thépaut, J. N., and Vitart, F.:: The ERA-Interim reanalysis: Configuration and performance of the data assimilation system. Quart. J. Roy. Meteor. Soc., 137, 553-597, 2011a.

Dee, D., Berrisford, P., Bosilovich, M. G., Chelliah, M., Compo, G., Ebita, A., Jones, P. D., Kobayashi, S., Kumar, A., Rutledge, G., Saha, S., Sato, H., Simmons, A., Smith, C. and Vose, R.: The use of reanalysis data for monitoring the state of the climate [in The State of the Climate in 2010], Bull. Amer. Meteor. Soc., 92, S34-S35, 2011b.

Dee, D. P. and Uppala, S.: Variational bias correction of satellite radiance data in the ERA-Interim reanalysis, Q. J. R. Meteorol. Soc., 135: 1830-841, doi:10.1002/qj.493, 2009.

Deutschmann, T., Beirle, S., Frieß, U., Grzegorski, M., Kern, C., Kritten, L., Platt, U., Pukite, J., Wagner, T., Werner, B., Pfeilsticker, K.: The Monte Carlo Atmospheric Radiative Transfer Model McArtim: Introduction and Validation of Jacobians and 3D Features, J. Quant. Spectr. Rad. Transf., 112, 1119-1137, doi:10.1016/j.jqsrt.2010.12.009, 2011.

du Piesanie, A., Piters, A. J. M., Aben, I., Schrijver, H., Wang, P., and Noël, S.: Validation of two independent retrievals of SCIAMACHY water vapour columns using radiosonde data, Atmos. Meas. Tech. Discuss., 6, 665-702, doi:10.5194/amtd-6665-2013, 2013.

Fennig, K., Andersson, A., Bakan, S., Klepp, C., and Schroeder, M.: Hamburg Ocean Atmosphere Parameters and Fluxes from Satellite Data - HOAPS 3.2 - Monthly Means / 6-Hourly Composites, Satellite Application Facility on Climate Monitoring, doi:10.5676/EUM_SAF_CM/HOAPS/V001, 2012.

Fournier, N., Stammes, P., de Graaf, M., van der A, R., Piters, A., Grzegorski, M., and Kokhanovsky, A.: Improving cloud information over deserts from SCIAMACHY Oxygen A-band measurements, Atmos. Chem. Phys., 6, 163-172, doi:10.5194/acp-6163-2006, 2006

Gaffen, D. J., Barnett, T. P., and Elliott, W. P.: Space and time scales of global tropospheric moisture, J. Clim., 4, 989-1008, 1991.

Gomer, T., Brauers, T., Heintz, F., Stutz, J., and Platt, U.: MFC user manual, version 1.98, inhouse publication, Institut für Umweltphysik, University of Heidelberg, Germany, 1-173, 1993.

Grossi, M., Kalakoski, N., and Valks, P.: O3M SAF ORR Validation Report, SAF/O3M/DLR/ORR/H2O, Issue 01/2013, 1-29, 2013. 
Grzegorski, M.: Cloud retrieval from UV/VIS satellite instruments (SCIAMACHY and GOME), PhD thesis, University of Heidelberg, 1-215, 2009.

Grzegorski, M., Frankenberg, C., Platt, U., Wenig, M., Fournier, N., Stammes, P., and Wagner, T.: Determination of cloud parameters from SCIAMACHY data for the correction of tropospheric trace gases, in: ESA-publication SP-572 (CD-ROM), Proceedings of the ENVISAT \& ERS Symposium, 6-10 September 2004, Salzburg, Austria, 2004.

Herman, J. R., Bhartia, P. K., Torres, O., Hsu, C., Seftor, C., and Celarier, E. A.: Global distributions of UV-absorbing aerosols from Nimbus-7 TOMS data, J. Geophys. Res., 102, 1691116922, 1997.

Hilton, F., Armante, R., August, T., Barnet, C., Bouchard, A., Camy-Peyret, C., Capelle, V., Clarisse, L., Clerbaux, C., Coheur, P.-F., Collard, A., Crevoisier, C., Dufour, G., Edwards, D., Faijan, F., Fourrié, N., Gambacorta, A., Goldberg, M., Guidard, V., Hurtmans, D., Illingworth, S., Jacquinet-Husson, N., Kerzenmacher, T., Klaes, D., Lavanant, L., Masiello, G., Matricardi, M., McNally, A., Newman, S., Pavelin, E., Payan, S., Péuignot, E., Peyridieu, S., Phulpin, T., Remedios, J., Schlüssel, P., Serio, C., Strow, L., Stubenrauch, C., Taylor, J., Tobin, D., Wolf, W., and Zhou, D.: Hyperspectral Earth Observation from IASI: Five Years of Accomplishments, Bull. Am. Meteorol. Soc., 93, 347370, doi:10.1175/BAMS-D-11-00027.1, 2012.

Hovila, J. and Hassinen, S.: Service Specification Document Issue 1.1, SAF/O3M/FMI/RQ/SESP/001, http://o3msaf.fmi.fi/ docs/O3M_AF_Service_Specification.pdf (last access: 3 March 2015), 2013

Kalakoski, N., Wagner, T., Mies, K., Beirle, S., Slijkhuis, S., and Loyola, D.: O3M SAF Validation Report, Offline Total Water Vapor, SAF/O3M/FMI/VR/H2O/111, 1-43, 2011.

Kalakoski, N., Kujanpää, J., Sofieva, V., Tamminen, J., Grossi, M., and Valks, P.: Comparison of GOME-2/Metop total column water vapour with ground-based and in situ measurements, Atmos. Meas. Tech. Discuss., 7, 12517-12543, doi:10.5194/amtd7-12517-2014, 2014.

Koelemeijer, R. B. A., Haan, J. F. D., and Stammes, P.: A database of spectral surface reflectivity in the range $335-772 \mathrm{~nm}$ derived from 5.5 years of GOME observations, J. Geophys. Res., 108, 4070, doi:10.1029/2002JD002429, 2003.

Lang, R., Williams, J. E., van der Zande, W. J., and Maurellis, A. N.: Application of the Spectral Structure Parameterization technique: retrieval of total water vapour columns from GOME, Atmos. Chem. Phys., 3, 145-160, doi:10.5194/acp-3-145-2003, 2003.

Lang, R., Casadio S., Maurellis, A. N., and Lawrence M. G.: Evaluation of the GOME Water Vapor Climatology 1995-2002, J. Geophys. Res. 112, D12110, doi:10.1029/2006JD008246, 2007.

Learner, R., Schermaul, R., Tennyson, J., Zobov, N., Ballard, J., Newnham, D., and Wickett, M.: Measurement of $\mathrm{H}_{2} \mathrm{O}$ Absorption Cross-Sections for the Exploitation of GOME data, ESTEC Contract No 13312/9/NL/SF, Final Presentation, 2000.

Li, J., Wolf, W. W., Menzel, W. P., Zhang, W., Huang, H. L., and Achtor, T. H.: Global soundings of the atmosphere from ATOVS measurements: The algorithm and validation, J. Appl. Meteorol., 39, 1248-1268, 2000.

Li, Z., Fielding, E. J., Cross, P. and Muller, J.-P.: Interferometric synthetic aperture radar atmospheric correction: MEdium
Resolution Imaging Spectrometer and Advanced Synthetic Aperture Radar integration, Geophys. Res. Lett., 33, L06816, doi:10.1029/2005GL025299, 2006.

Lichtenberg, G., Bovensmann, H., Van Roozendael, M., Doicu, A., Eichmann, K.-U., Hess, M., Hrechanyy, S., Kokhanovsky, A., Lerot, C., Noel, S., Richter, A., Rozanov, A., Schreier, F. and Tilstra, L.G.: SCIAMACHY Offline Level 1b-2 Processor ATBD (ENV-ATB-QWG-SCIA-0085, issue 1A), 1-137, 2010.

Lindstrot, R., Preusker, R., Diedrich, H., Doppler, L., Bennartz, R., and Fischer, J.: 1-D-Var retrieval of daytime total columnar water vapour from MERIS measurements, Atmos. Meas. Tech. Discuss., 4, 6811-6844, doi:10.5194/amtd-4-6811-2011, 2011.

Lindstrot, R., Preusker, R., Diedrich, H., Doppler, L., Bennartz, R., and Fischer, J.: 1D-Var retrieval of daytime total columnar water vapour from MERIS measurements, Atmos. Meas. Tech., 5, 631646, doi:10.5194/amt-5-631-2012, 2012.

Loyola, D., Valks, P., Ruppert, T., Richter, A., Wagner, T., Thomas, W., van der A, R., and Meisner, R.: The 1997 El Niño impact on clouds, water vapour, aerosols and reactive trace gases in the troposphere, as measured by the Global Ozone Monitoring Experiment, Adv. Geosci., 6, 267-272, doi:10.5194/adgeo-6-267-2006, 2006.

Loyola, D., Thomas, W., Livschitz, Y., Ruppert, T., Albert, P., and Hollmann, R.: Cloud properties derived from GOME/ERS2 backscatter data for trace gas retrieval, IEEE T. Geosci. Sens., 45, 2747-2758, 2007.

Loyola D., Thomas, W., Spurr, R., Mayer, B.: Global patterns in daytime cloud properties derived from GOME backscatter UVVIS measurements, Int. J. Remote Sens., 31, 4295-4318, 2010.

Loyola D., Koukouli M. E., Valks P., Balis D. S., Hao N., Van Roozendael M., Spurr R. J. D., Zimmer W., Kiemle S., Lerot C., Lambert J.-C: The GOME-2 total column ozone product: Retrieval algorithm and ground-based validation, J. Geophys. Res., 116, D07302, 2011.

Maurellis, A. N., Lang, R., Van der Zande, W. J., Ubachs, W, and Aben, I: Precipitable Water Column Retrieval from GOME, Geophys. Res. Lett., 27, 903-906, 2000.

Mieruch, S., Noël, S., Bovensmann, H., and Burrows, J. P.: Analysis of global water vapour trends from satellite measurements in the visible spectral range, Atmos. Chem. Phys., 8, 491-504, doi:10.5194/acp-8-491-2008, 2008.

Mieruch, S., Schröder, M., Noël, S., and Schulz, J.: Comparison of monthly means of global total column water vapour retrieved from independent satellite observations, J. Geophys. Res., 115, D23310, doi:10.1029/2010JD013946, 2010.

Minschwaner, K., and Dessler, A. E.: Water vapor feedback in the tropical upper troposphere: Model results and observations, J. Clim., 17, 1272-1282, 2004.

Munro, R., Eisinger, M., Anderson, C., Callies, J., Corpaccioli, E., Lang, R., Lefebvre, A., Livschitz, Y., and Perez Albinana, A.: GOME-2 on MetOp: From in-orbit verification to routine operations, in: Proceedings of EUMETSAT Meteorological Satellite Conference, Helsinki, Finland, 12-6 June, 1-8, 2006.

Noël, S., Buchwitz, M., Bovensmann, H., Hoogen, R., and Burrows, J. P.: Atmospheric Water Vapor Amounts Retrieved from GOME Satellite Data, Geophys. Res. Lett. 26, 1841 pp., 1999.

Noël, S., Mieruch, S., Bovensmann, H., and Burrows, J. P.: Preliminary results of GOME-2 water vapour retrievals and first ap- 
plications in polar regions, Atmos. Chem. Phys., 8, 1519-1529, doi:10.5194/acp-8-1519-2008, 2008.

Ogawa, T., Shimoda, H., Hayashi, M., Imasu, R., Ono, A., Nishinomiya, S., and Kobayashi, H.: IMG, Interferometric measurement of greenhouse gases from space, Adv. Space. Res., 14, 25 28, 1994.

Phalippou, L.: Variational retrieval of humidity profile, wind speed and cloud liquid-water path with the SSM/I: Potential for numerical weather prediction, Q. J. R. Meteor. Soc., 122, 327-355, 1996.

Platt, U.: Differential optical absorption spectroscopy (DOAS), in Air Monitoring by Spectroscopic Techniques, Chem. Anal. Ser., vol. 127, edited by: Sigrist, M. W., 27-84, John Wiley, Hoboken, N. J., 1994.

Rocken, C., Ware, R. H., Van Hove, T., Solheim, F., Alber, C., and Johnson, J.: Sensing atmospheric water vapour with the Global Positioning System, Geophys. Res. Lett., 20, 2631-2634, 1993.

Rocken, C., Van Hove, T., and Ware R. H.,: Near real-time GPS sensing of atmospheric water vapour, Geophys. Res. Lett., 24, 3221-3224, 1997.

Rocken, C., Kuo, Y.-H.,Schreiner, W., Hunt, D., Sokolovskiy, S., and McCormick, C.: COSMIC system description, Terr. Atmos. Oceanic Sci., 11, 21-52, 2000.

Rothman, L. S., Gordon, I. E., Barbe, A., Benner, D. Chris, Bernath, P. F., Birk, M., Boudon, V., Brown, L. R., Campargue, A., Champion, J. P., Chance, K., Coudert, L. H., Dana, V., Devi, V. M., Fally, S., Flaud, J.-M., Gamache, R. R., Goldman, A., Jacquemart, D., Kleiner, I., Lacome, N., Lafferty, W. J., Mandin, J.-Y., Massie, S. T., Mikhailenko, S. N., Miller, C. E., Moazzen-Ahmadi, N., Naumenko, O. V., Nikitin, A. V., Orphal, J., Perevalov, V. I., Perrin, A., Predoi-Cross, A., Rinsland, C. P., Rotger, M., Šimečková, M., Smith, M. A. H., Sung, K., Tashkun, S. A., Tennyson, J., Toth, R. A., Vandaele, A. C., and Van der Auwera, J.: The HITRAN 2008 molecular spectroscopic database, J Quant Spectrosc Radiat Transfer, 110, 533-72, 2009.

Schröder, M., Slijkhuis, S., and Wagner, T.: DUE GLOBVAPOUR Algorithm Theoretical Baseline Document (ATBD) for L3 GOME+SCIAMACHY+GOME-2, Issue 3, Revision 0, 19 January 2012a.

Schröder, M., Lindstrot, R., and Schneider, N.; DUE GLOBVAPOUR Algorithm Theoretical Baseline Document (ATBD) for L3 SSMI+MERIS, Issue 3, Revision 0, 19 January 2012b.

Schröder, M. and Schneider, N.; DUE GLOBVAPOUR Product Validation Report (PVR) Cross-Comparison, Issue 1, Revision 1, 21 August 2012c.

Schröder, M., Saunders, R., and Ringer, M.; DUE GLOBVAPOUR Scientific Exploitation Plan (SEP), Issue 1, Revision 0, 17 April 2012d.

Shephard, M. W, Herman, R. L., Fisher, B. M., Cady-Pereira, K. E., Clough, S. A., Payne, V. H., Whiteman, D. N., Comer, J. P., Vömel, H., Miloshevich, L. M., Forno, R., Adam, M., Osterman, G. B., Eldering, A., Worden, J. R., Brown, L. R., Worden, H. M., Kulawik, S. S., Rider, D. M., Goldman, A., Beer, R., Bowman, K. W., Rodgers, C. D., Luo, M., Rinsland, C. P., Lampel, M., and Gunson, M. R.: Comparison of Tropospheric Emission Spectrometer Nadir Water Vapor Retrievals with In Situ Measurements, J. Geophys. Res., 113, D15S24, doi:10.1029/2007JD008822, 2008.
Slijkhuis, S., Beirle, S., Kalakoski, N., Mies, K., Wagner, T., Noël, S., Schulz, J.: Comparison of $\mathrm{H}_{2} \mathrm{O}$ retrievals from GOME and GOME-2, Proc. Eumetsat, 55 pp., 2009.

Solomon, S., Miller, H. L., Smith, J. P., Sanders, R. W., Mount, G. H., Schmeltekopf, A. L., and Noxon, J. F: Atmospheric NO3 1. Measurement Technique and the Annual Cycle, J. Geophys. Res., 94, 11041-11048, 1989.

Spurr, R., de Haan, J. F., van Oss, R., and Vasilkov, A.: Discrete ordinate radiative transfer in a stratified medium with first order rotational Raman scattering, J. Quant. Spectrosc. Radiat. Transfer, 109, 404-425, 2008.

Susskind, J., Barnet, C. D., and Blaisdell, J. M.: Retrieval of atmospheric and surface parameters from AIRS/AMSU/HSB data in the presence of clouds, IEEE T. Geosci. Remote Sens., 41, 390409, 2003.

Torres, O., Bhartia, P. K., Herman, J. R., Ahmad, Z., and Gleason, J. F.: Derivation of aerosol properties from satellite measurements of backscattered ultraviolet radiation: Theoretical basis, J. Geophys. Res., 103, 17099-17110, 1998.

Trenberth, K. E. and Stepaniak, D. P.: Co-variability of components of poleward atmospheric energy transports on seasonal and interannual timescales, J. Climate, 16, 3691-3705, 2003.

Trenberth, K. E., Smith, L., Qian, T., Dai, A., and Fasullo, J.: Estimates of the global water budget and its annual cycle using observational and model data, J. Hydrometeor., 8, 758-769, 2007.

Valks, P., Loyola, D., Hao, N., Rix M., and Slijkhuis, S.: Algorithm Theoretical Basis Document for GOME-2 Total Column Products of Ozone, Minor Trace Gases and Cloud Properties (GDP 4.5 for O3M-SAF OTO and NTO), DLR/GOME-2/ATBD/01, Iss./Rev.: 2/GG, 2012.

Van Roozendael, M., Fayt, C., Lambert, J.-C., Pundt, I., Wagner, T., Richter, A., and Chance, K.: Development of a bromine oxide product from GOME, in Proceedings of the European Symposium on Atmospheric Measurements From Space (ESAMS 99), 18 to 22 Jan., ESTEC, Noordwijk, Netherlands, Rep. WPP-161, 543-547, Eur. Space Agency, Noordwijk, Netherlands, 1999.

Wagner, T., Otten, C., Pfeilsticker, K., Pundt, I., and Platt, U.: DOAS moonlight observation of atmospheric NO3 and NO2 in the Arctic winter, Geophys. Res. Lett, 27, 3441-3444, 2000.

Wagner, T., Heland, J., Zöger, M., and Platt, U.: A fast $\mathrm{H}_{2} \mathrm{O}$ total column density product from GOME - Validation with in situ aircraft measurements, Atmos. Chem. Phys., 3, 651-663, doi:10.5194/acp-3-651-2003, 2003.

Wagner, T., Beirle, S., Grzegorski, M., Sanghavi, S., and Platt, U.: El-Nino induced anomalies in global data sets of total column precipitable water and cloud cover derived from GOME on ERS-2, J. Geophys. Res., 110, doi:10.1029/2005JD005972, 1642, 2005.

Wagner, T., Beirle, S., Grzegorski, M., and Platt, U: Global trends (1996-2003) of total column precipitable water observed by Global Ozone Monitoring Experiment (GOME) on ERS-2 and their relation to near-surface temperature, J. Geophys. Res. 111, D12102, doi:10.1029/2005JD006523, 2006.

Wagner, T., Beirle, S., Deutschmann, T., Grzegorski, M., and Platt, U.: Satellite monitoring of different vegetation types by differential optical absorption spectroscopy (DOAS) in the red spectral range, Atmos. Chem. Phys., 7, 69-79, doi:10.5194/acp-7-692007, 2007. 
Wagner, T., Beirle, S., and Deutschmann, T.: Three-dimensional simulation of the Ring effect in observations of scattered sun light using Monte Carlo radiative transfer models, Atmos. Meas. Tech., 2, 113-124, doi:10.5194/amt-2-113-2009, 2009.

Wagner, T., Beirle, S., and Mies, C.: Description of the MPIMainz H2O retrieval (Version 5.0, March 2011), technical document, http://www.sciamachy.org/products/H2O/H2Ovc_IUP_ AD.pdf (last access: 3 March 2015), 2011.

Wang, J., Cole, H. L., Carlson, D. J., Miller, E. R., Beierle, K., Paukkunen, A., and Laine, T. K.: Corrections of humidity measurement errors from the Vaisala RS80 radiosonde-Application to TOGA COARE data, J. Atmos. Oceanic Technol., 19, 981$1002,2002$.
Wentz, F. J.: A well-calibrated ocean algorithm for SSM/I, J. Geophys. Res., 102, No. C4, 8703-8718, 1997.

Wentz, F. J.: SSM/I Version-7 Calibration Report, report number 011012, Remote Sensing Systems, Santa Rosa, CA, 46 pp., 2013.

Worden, J., Kulawik, S., Frankenberg, C., Payne, V., Bowman, K. Cady-Peirara, K., Wecht, K., Lee, J.-E., and Noone, D.: Profiles of $\mathrm{CH}_{4}, \mathrm{HDO}, \mathrm{H}_{2} \mathrm{O}$, and $\mathrm{N}_{2} \mathrm{O}$ with improved lower tropospheric vertical resolution from Aura TES radiances, Atmos. Meas. Tech., 5, 397-411, doi:10.5194/amt-5-397-2012, 2012. 